e

DUURIEY IIITO AGROFORESTRY IEADENS GUDE

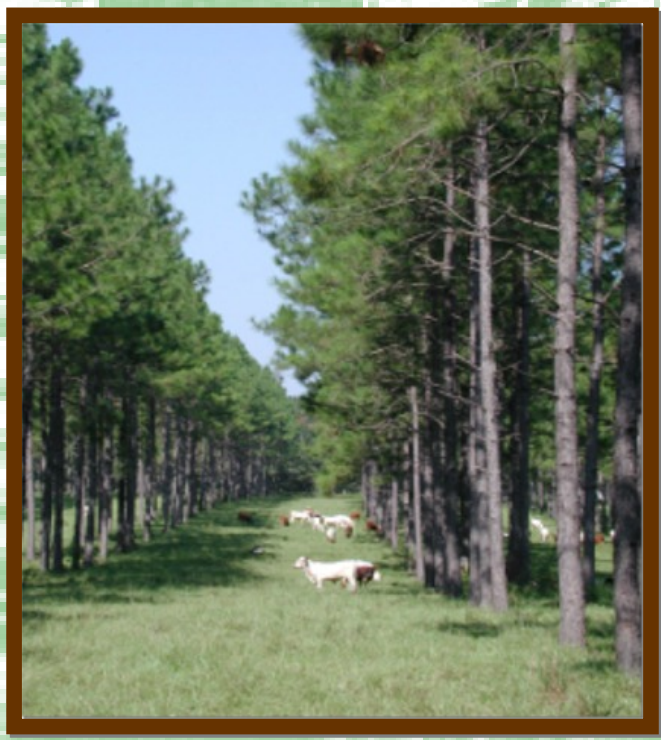

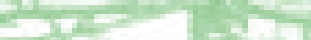

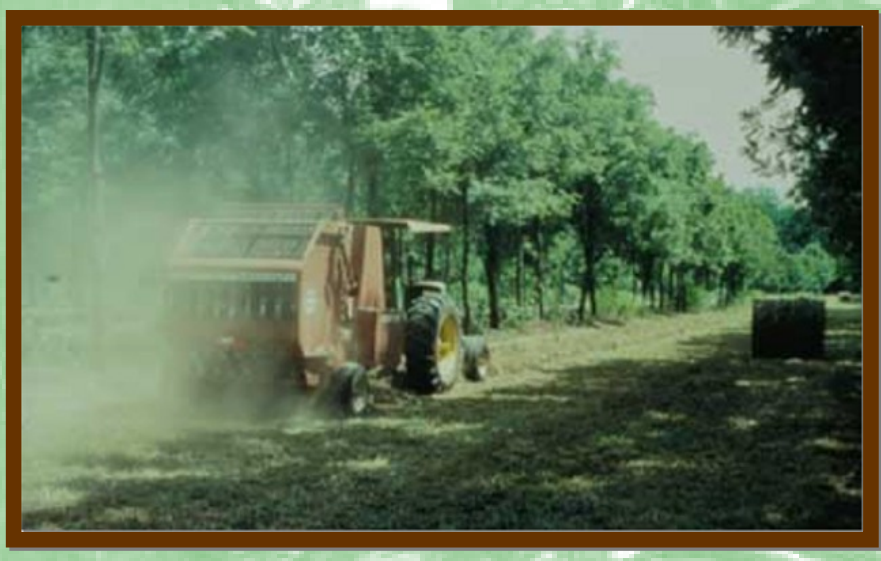

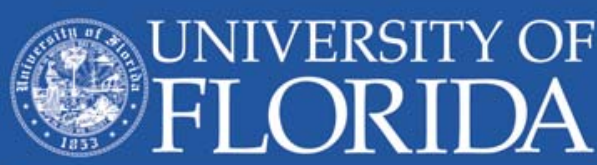

IFAS EXTENSION
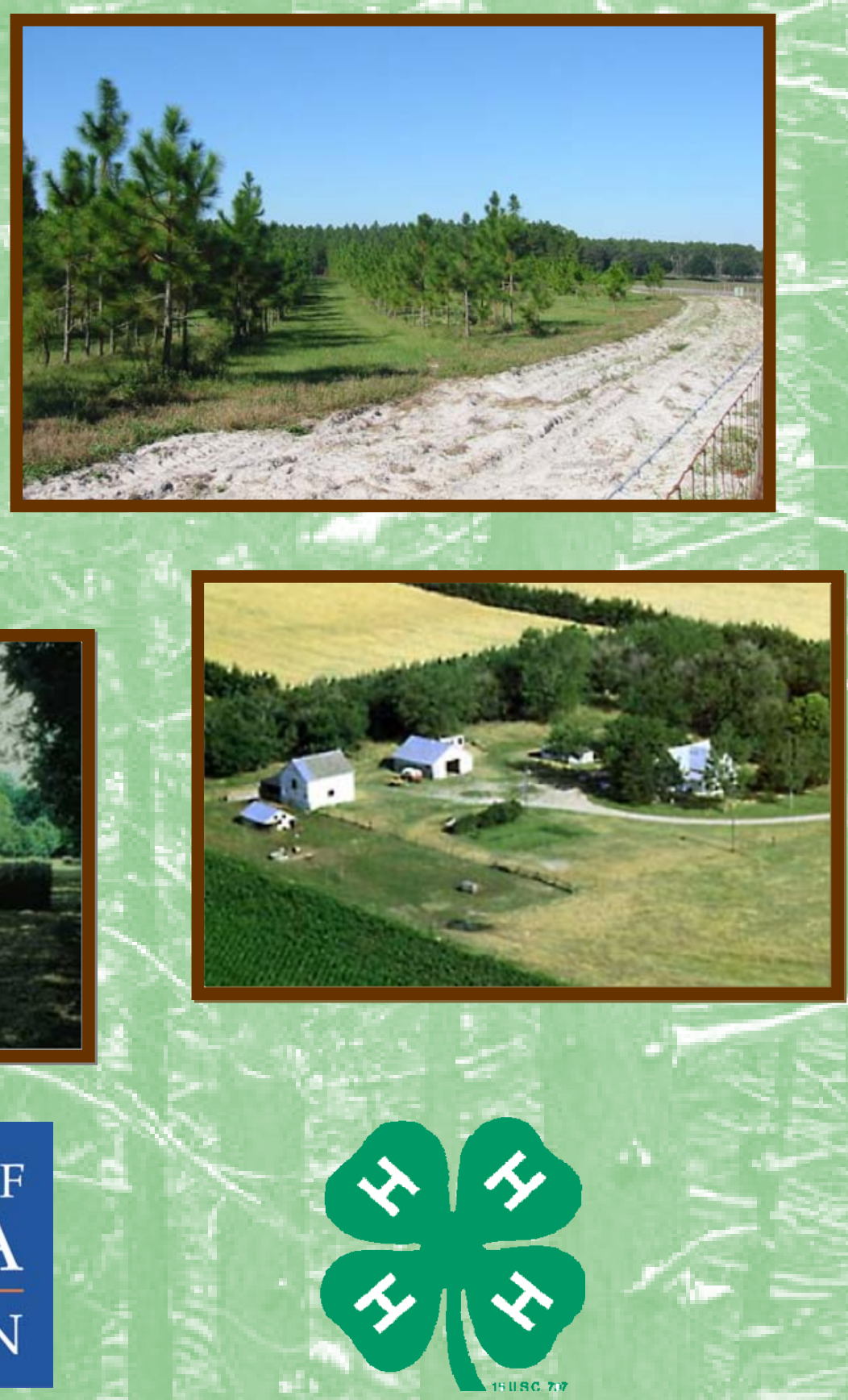


\section{Project Goals and Objectives}

Welcome to the Leader's Guide for the Journey into Agroforestry Project Book. The accompanying Project Book was written for youth, ages 12 and beyond. The activities in that book ask youth to explore their community, ask questions, seek information, and create potential land management plans. For the individual youth, the Project Book may be used in its entirety as 9 activities. If not, it is recommended that youth complete activities 1.1 and 1.2 and then pick and choose from the remaining activities. Each activity and many of the challenges are designed to help youth practice important life skills while learning how to think of alternative solutions to current land management challenges through agroforestry. This Leader's Guide also offers suggestions for managing groups of youth who are completing the Agroforestry Project Book.

\section{Your Role as a Project Helper/ Leader:}

In this Project Book, youth are encouraged to be self-directed learners. However, the leader plays many important roles and helps the youth use their project books to the fullest. This means that you will need to:

- Read through the Project Book and Leader's Guide to become familiar with the subject matter, learning objectives, and activities.

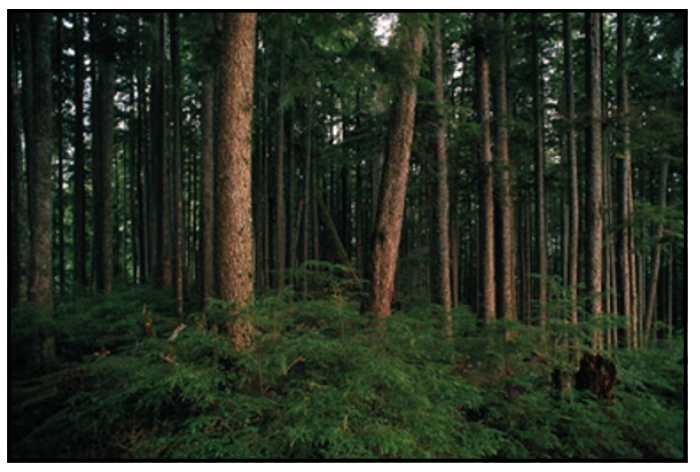

- Help facilitate and organize activities: provide transportation, materials, and connect youth with people in the community that are knowledgeable about the topic.

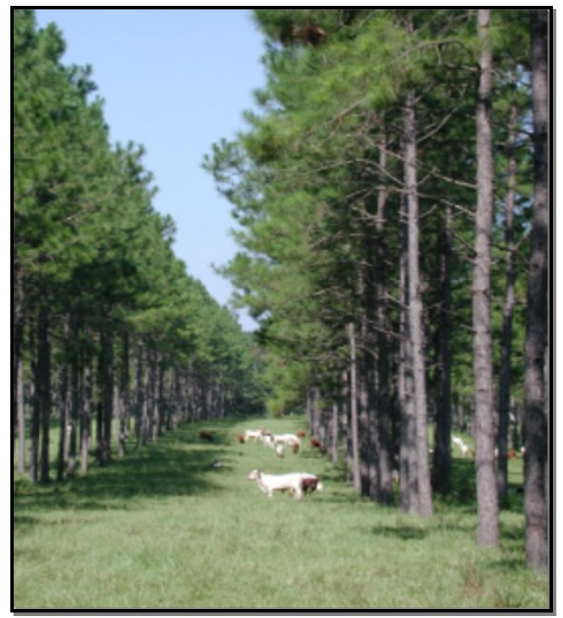

- Help guide youth through the experiential learning questions. Make sure to ask youth the questions in each activity "Share with your helper." Help answer and discuss any questions the youth may have in the "Let's Talk" section.

- Provide more information about careers. You can bring in guest speakers and take field trips to see what skills are needed in real careers.

- Provide a safe, supportive environment for youth. 

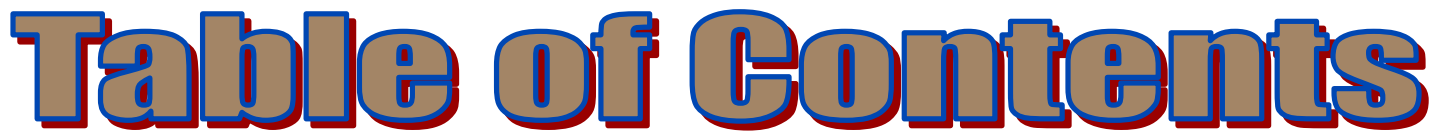

\section{Introduction}

Welcome to a Journey into Agroforestry

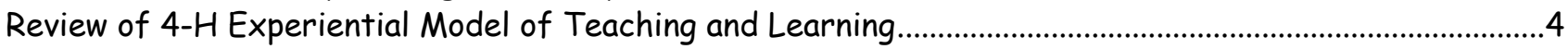

Agroforestry Achievement Program

\section{Chapter 1: Introducing Agroforestry}

Introduction to current agriculture, animal pasture and forest plantation practices- Activity $1.1 \ldots \ldots \ldots . . . .5$

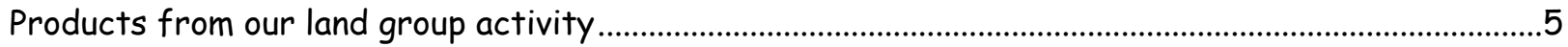

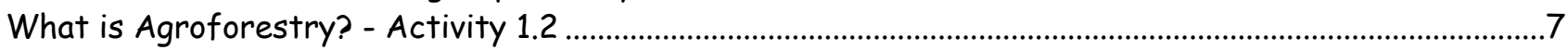

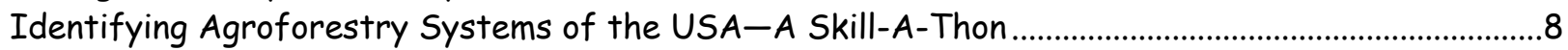

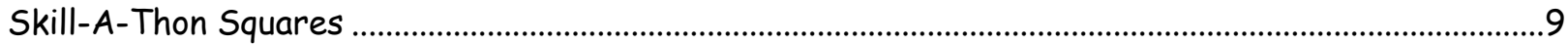

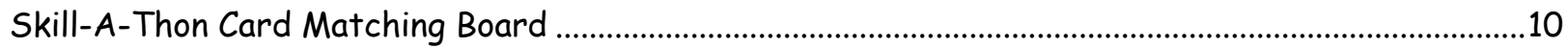

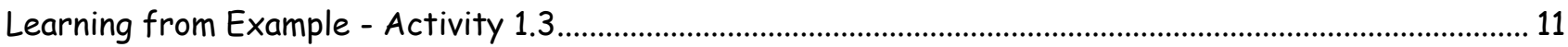

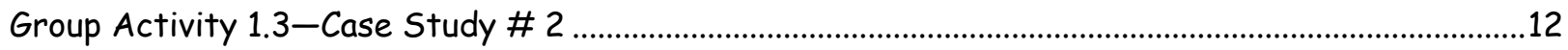

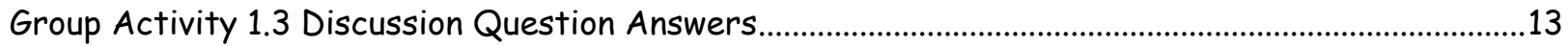

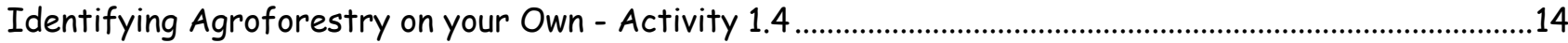

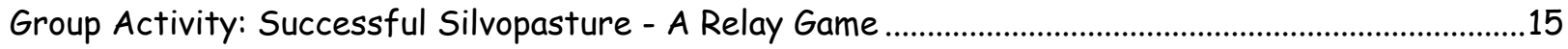

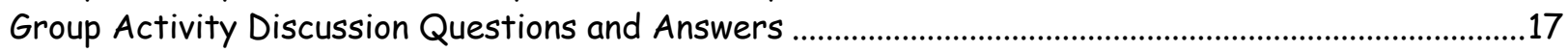

\section{Chapter 2: Is Agroforestry Right for You?}

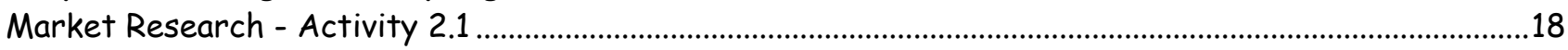

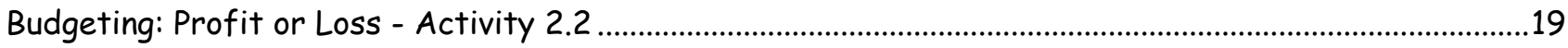

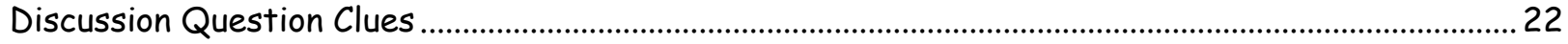

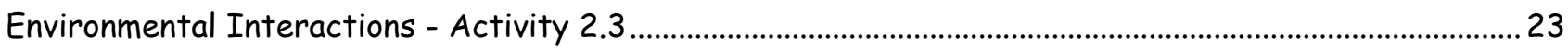

\section{Chapter 3: Agroforestry Action}

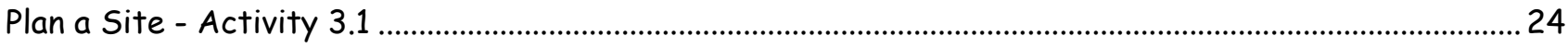

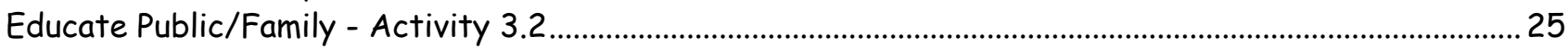

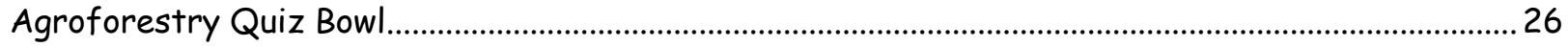

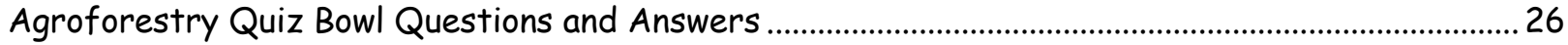

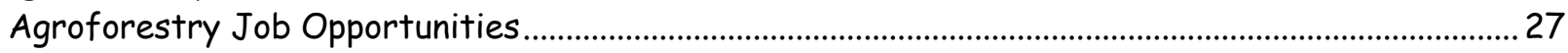

Game Cards

\section{Agroforestry Resources}

A variety of resources can be found at your library, at your county extension office, and on the internet to help you explore the potentials of agroforestry.

\section{Websites:}

The Center for Subtropical Agroforestry, Gainesville, FL:

http://cstaf.ifas.ufl.edu/index.htm

Florida Agroforestry tree database:

http://cstaf.ifas.ufl.edu/tree\&shrubdb.asp

The Association for Temperate Agroforestry focuses on agroforestry in temperate North America. http://www.aftaweb.org/

Agroforestry Net, Worldwide agroforestry email journal: http://www.agroforestry.net

World Agroforestry Center:

http://www.worldagroforestry.org/ 


\section{Review of the 4-H Experiential Model of Teaching and Learning}

The activities in this book were designed to include the three basic steps in the Experiential Learning Model. Each activity teaches a concept through an experience of exploration or investigation, providing new information with readings or observations. The concept is strengthened through reflective questions that help the youth focus on their observations and experiences. Additional questions prompt learners to imagine new applications of each concept.

This hands-on approach to learning is what distinguishes experiential learning from traditional education. The youth-driven model of learning gives youth flexibility to decide how they want to learn. As you can see from the Experiential Learning Model, youth start by doing an activity on their own. Then with the leader's guidance, youth reflect on what they did and how they can apply the learning in other situations. As a 4-H helper, it is your responsibility to provide the setting for the experiential learning to occur. Allow the youth to make discoveries on their own. Take on the role of a mentor or coach, providing support and guidance only when needed.

\section{Teaching and Managing Youth}

Children learn best when they actively engage in they want to be when they grow up. They also the learning process and feel comfortable in the learning environment. An understanding of the general characteristics of the age group you are working with will help youth get the most from their activities. While youth develop at different paces, the following paragraphs provide the common interests and needs of youth, ages 12 and beyond.

Youth ages 12 and up are often concerned about their physical development and being liked by their friends. Youth at this age are ready for in-depth, longer learning experiences. They can grasp abstract concepts and they like to find their own solutions to problems. They want to explore the world beyond their own community. They are starting to think about what like working with teens or adults whom they admire. They seek independence yet want and need their parents' help.

Your strategy for this age group is to provide a supportive environment for testing new ideas and skills. Encourage learning activities that help youth understand themselves and others. Assist youth in developing individual skills. Provide hands-on, skill-based experiences that relate to the project. Relate the life skills learned to career choices. As a leader, provide supervision and assistance, but avoid interference.

Youth at this age need to feel accepted and valued. Take great care not to embarrass them and to avoid comparing young people with each other.

\section{Group Techniques}

The Journey into Agroforestry Project Book can be used with groups of youth. This leader guide not only provides you with background information to assist a single youth, it outlines directions for using the Project Book with groups of youth. There are a few supplemental group activities like the relay, knowledge quiz bowls or other games that can be used at anytime to supplement the Youth Project Guide. 
The Project Book will help youth learn about how to enhance current and future farms through diversifying activities. According to the 2002 Census of Agriculture, $30 \%$ of the land of Florida is in agriculture and animal pasture. Tree plantations cover an additional 14\% of the land or 4.6 million acres of state. Our lives depend on the vegetables, animals, and wood products that are harvested from these lands. While we depend on these products, we also depend on a healthy environment. Managing this large amount of land in ways that simultaneously produce the products we need, while taking extra care of the environment is important for our future. Careful management will help landowners sustain their activities for generations to come.

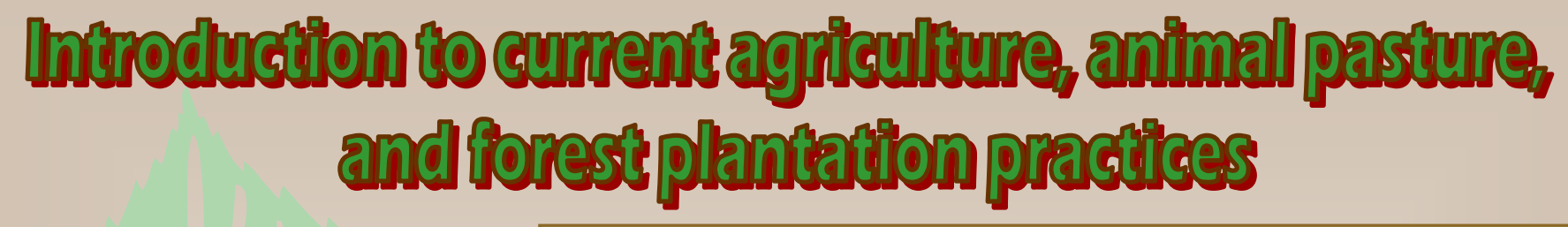

\section{Activity 1.1}

Learning Goal:

Youth will be able to explain the similarities and differences between traditional agriculture, rangeland, and forestry.

\section{Group Activity Instructions}

Field trip to (or visit on-line) three land management systems: agriculture field, pasture with livestock and tree plantation or forest.

- Review introduction and activity in Project Book to facilitate activity.

- Divide youth in teams of 2 or 3 .

- Each team will use one Project Book to work through activity together.

- After completing activity, ask youth to work with their team to write discussion questions answers in shared Project Book to prepare for group discussion.

- Gather all youth and lead group discussion using discussion questions in Project Book.

A field of crops, a pasture with animals, and a plantation of trees are all managed for a profit. The land owner is generating a product to sell. These products, whether they are cows, corn, or trees are raised under the careful management of the farmer/land owner. Each system requires specific inputs for success. The land owners in charge follow strategic plans for reaching their objectives.

These three systems distinguish and differentiate themselves by many factors. One factor is the time frame required for the first harvest. For example, in an agriculture system, the product may be harvested one to two times a year. Animals may take three to ten years until they are ready to be sold. Tree plantations take the longest at 20 to 50 years although some products may be available sooner. Other distinguishing factors include the products, the climate, and soil conditions.

Most often on large scale operations, one product is grown. This is called monoculture. This is a simple and convenient way of planting, cultivating and harvesting a crop or trees. In agriculture, the land owner has to buy 
(Continued from page 5)

or rent planting and harvesting equipment for only one type of crop. Although this has been the method of choice for recent farmers in the USA, monoculture can be detrimental for nutrient, pest and yield management. This is why farmers often rotate crops although even rotation of monoculture crops does not work in all cases.

Recently, there has been a movement to diversify farm products to maintain the health of the land. Advantages of crop diversification include: stability of yields, reduced potential pest and fungal invasion, and reduced need for chemicals to control these pests. There is also the potential for greater economic benefits.

"Products" of a farm can include anything that generates money. For example, a landowner that is managing forest may sell hunting permits. Pine plantations often produce large amounts of needles that can be collected for mulch. Anything you may be able to collect in the forest that you can sell is a product.

\section{Tips for Field Trips}

- Do you have signed permission slips from all parents? Remember to carry emergency information with you at all times.

- Do you have your first aid kit wellstocked?

- Have you made a note of all allergies that children may have? Bring along medication, inhalers, and beesting kits if needed.

- Have you planned for the weather? Bring along hats, sunscreen, rain gear, and layers for changing weather.

- Have you packed snacks and drinks? Small bags of trail mix, granola bars, or cereal can be easily transported. In some places, water may not be available. Bring along a large jug, paper cups or juice boxes.

- Always call ahead to confirm hours, fees, or double check with the host.

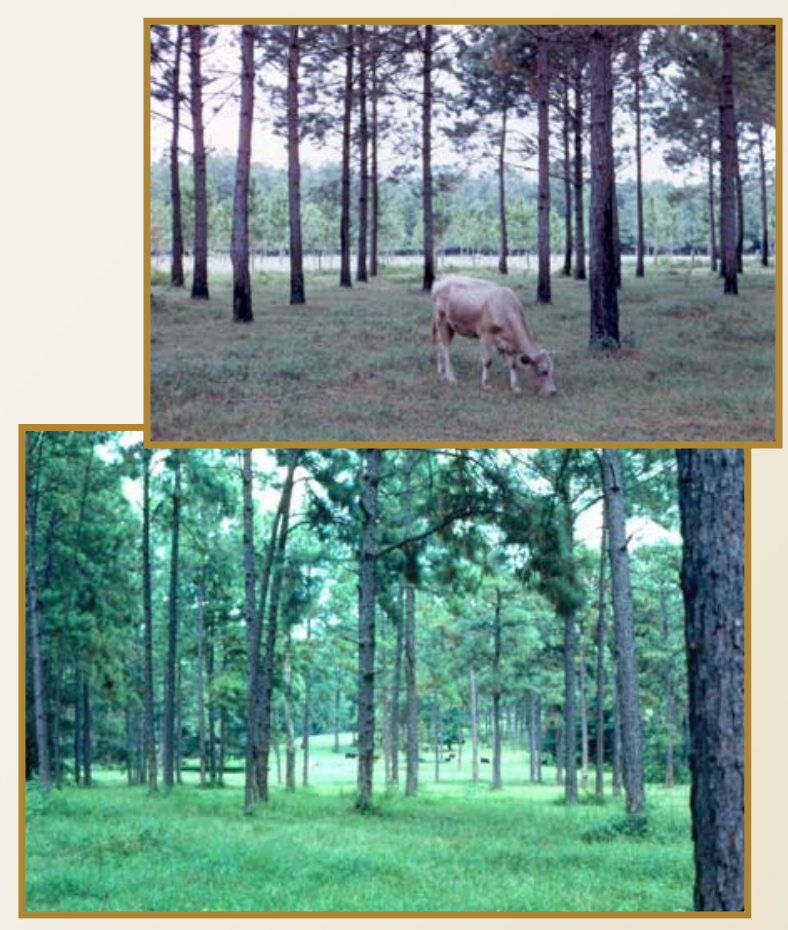




\section{What is Agroforestring}

\section{Activity 1.2}

\section{Learning Goal:}

Youth will be able to explain the characteristics of each agroforestry practice.

\section{Group Activity Instructions}

- Conduct an Agroforestry Skill-A-Thon.

- Review background \& activities in Project Book.

- Make 4 copies of the Agroforestry Poster on page 10.

- Make a copy of Skill-A-Thon squares and cut out.

- Make a sign with tasks for each station.

- Divide youth into small groups of 2-5 to rotate and complete each station.

- Make supplies available: Agroforestry Poster and "word squares."

- After groups go through all stations, gather entire group and go over discussion questions in the Project Book.
Agroforestry can be defined in many ways as it combines trees, shrubs, forages, grasses, livestock and crops. Agroforestry is the combination of agriculture, ranch, and forestry practices that can conserve and produce natural resources while increasing benefits at the farm and community level. Agroforestry leaves the agriculture or ranch land in production while integrating trees into these operations. Farmers today are struggling with many challenges to make their family farm or forest profitable, productive and environmentally sustainable. Agroforestry is one land management option to overcome these challenges.

Agroforestry may take on many forms in or near your community. It may be in the form of a buffer of trees near a lake or stream, or it may be a strip of trees along the property line of a pasture for protection from the road or wind. All agroforestry systems strive to mimic natural ecosystems by utilizing the beneficial connections between trees and other living organisms. Agroforestry systems are composed of multiple layers of vegetation, similar to forests. A forest contains the upper canopy of the tallest trees, a sub-canopy of smaller trees, and the understory vegetation growing in the shade. Farmers can diversify product and farm income by utilizing these layers. Nutrient cycling and nutrient absorption is another characteristic that both agroforestry and natural system maintain. Riparian forest buffers absorb excess nutrients before they reach the water supply. Other potential benefits of all agroforestry systems include: improving soil quality and reducing soil erosion, increasing biodiversity, and a reduction in pest management inputs.

There are many tree and shrub options. The types of plants you can grow depend on your region. The youth can find these on-line, or use your personal knowledge. What do you see at the farmer's market that is grown locally? What type of tree is grown for timber sale or forest production? For example, in Florida, a land owner may choose slash and longleaf pine for a silvopasture system. For windbreaks, imagine trees that have many braches and block the wind - or maybe ones that produce fruit? For alley cropping, you can plant fruit producing trees and between the trees plant whatever crop you like: squash, lettuce, beans; the possibilities are endless. With forest farming, you can grow shiitake mushrooms or start out camellia plants in pots to sell as ornamentals. One goal of agroforestry is to harvest as many products as the land and market place can support.

No matter if you live in a rural or urban community, agroforestry can be applied with a little creativity. Think about what issues land owners deal with regularly and identify the environmental problems that might be solved. For example, are there heavy winds in your area? Wind breaks can be planted to shelter animals or buildings from the wind. Are the temperatures extreme during the summer or winter? Silvopasture trees can shade animals from snow or extreme heat. Agroforestry can be used at your community garden, park, schoolyard or backyard. Is the creek, river, or pond water inhabitable for fish and other aquatic animals? Riparian forest buffers of trees, shrubs, and grasses can reduce runoff into bodies of water and keep it clean. If there is an area in your community, home or school that is shaded, you can forest farm by growing mushrooms, flowers, ferns or other plants for garden use.

Despite the many benefits of agroforestry, there are many reasons it may be challenging to get land owners to try agroforestry. This may be a large change from land management practices the land owner is familiar with. There are monetary risks involved, as with starting any new type of business. There may be up-front costs involved, such as the need to buy new farm equipment. 


\section{Identifying Agroforestry Systems of the USA: A Skill-A-Thon}

In order for groups of youth to understand the basics of agroforestry, they will participate in an Agroforestry Skill-aThon. Four stations will represent four aspects of agroforestry that are necessary as the foundation of knowledge to expand on learning about this topic.

\section{Setting Up Stations}

Each station should have a standup sign that clearly indicates the topic of learning. After reading the sign, the teams should be able to match the description in the "word squares" to the corresponding pictures of agroforestry on the poster.

\section{The Station Facilitator}

The responsibilities of the station facilitator:

1. Become familiar with the topic from the background provided in the Leader's Guide

2. Develop questions to ask youth if they get stuck

3. Facilitate the station for each team in the following manner:

- Step back and allow the teams to figure it out for themselves.

- Respond to teams' questions with questions so answers are their own.

- Accept teams solutions

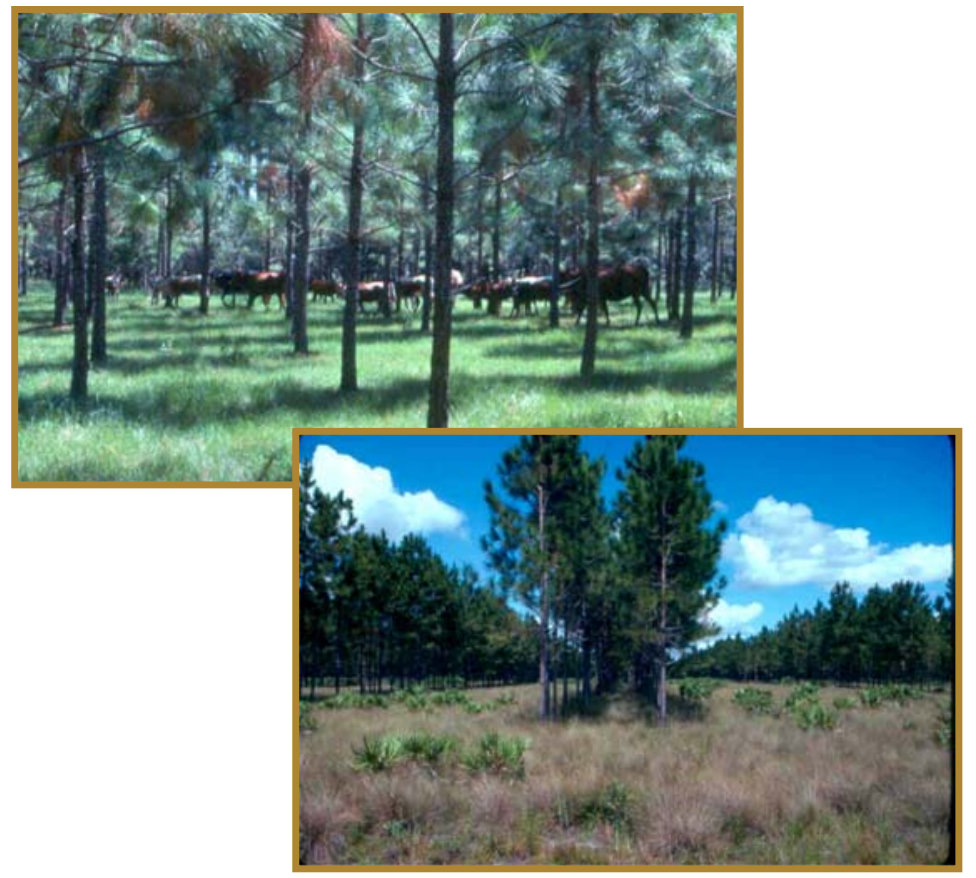

\section{Station Starters}

\section{Identifying agroforestry systems}

Situation: Classify agroforestry systems based on their characteristics.

Youth task: Match the agroforestry definition with the correct picture.

Materials: Agroforestry poster and cutouts of definitions.

\section{Matching products with agroforestry systems}

Situation: Understand what products can grow in each agroforestry system.

Youth task: Match the list of products with the correct picture of agroforestry. Materials: Agroforestry poster and cutouts of products.

\section{Matching land owner benefits with agroforestry systems}

Situation: Understand how land owners benefit from each agroforestry system. Youth task: Match the land owner benefits with the correct picture of agroforestry. Materials: Agroforestry poster and cutouts of land owner benefits.

\section{Matching environmental benefits with agroforestry systems}

Situation: Understand how each agroforestry system protects the environment. Youth task: Match the environmental benefits with the correct picture of agroforestry.

Materials: Agroforestry poster and cutouts of environmental benefits.

$$
\begin{gathered}
\text { Answer Key for Skill-A-Thon } \\
\text { Definitions } \\
\text { SP - A, RFB - B, AC - C, FF - E, WB - D } \\
\text { Products } \\
\text { SP - D, RFB - F, AC - A, FF - C, WB - B } \\
\text { Benefits for land owner } \\
\text { SP - C, RFB - D, AC - F, FF - A, WB - E } \\
\text { Environmental benefits } \\
\text { SP - E, RFB - C, AC - B, FF - D, WB - F }
\end{gathered}
$$




\section{Skill-a-Thon Squares}

Copy this page and cut out squares. Use with board on next page.

\section{Definition}

A system which combines trees with pasture and livestock production.

Definition $--B$

A strip of trees, shrubs, and plants grown beside a river, stream or

lake. This area can be managed to harvest products while also protecting water quality.

\section{Products}

Livestock (cattle, goats, horses), lumber, pasture, hay

$=-\bar{E}=\overline{=}=\overline{\bar{A}}$

\section{Products}

- Lumber, nuts, vegetables, berries, hay, fruit, ornamentals

- The largest variety of products of any system

\section{Environmental benefits}

- Reduces water runoff and erosion

- Provides more diverse habitat than single crops

- Organic matter returned to soil

- Cycles nutrients from different soil depths

\section{Environmental benefits}

- Reduction in air pollution caused by release of methane gas from cows.

- Ability to recycle water to reuse on crops

\section{Benefits for land owner}

- Cultivating area that would normally be managed for the one product of trees

- Utilizing natural shade to grow plants opposed to building a shade structure

\section{Benefits for land owner}

- Harvesting products from land that typically serves solely as environmental protection

- Wildlife viewing 


\section{What is Agroforestry Skill-A-Thon Poster}
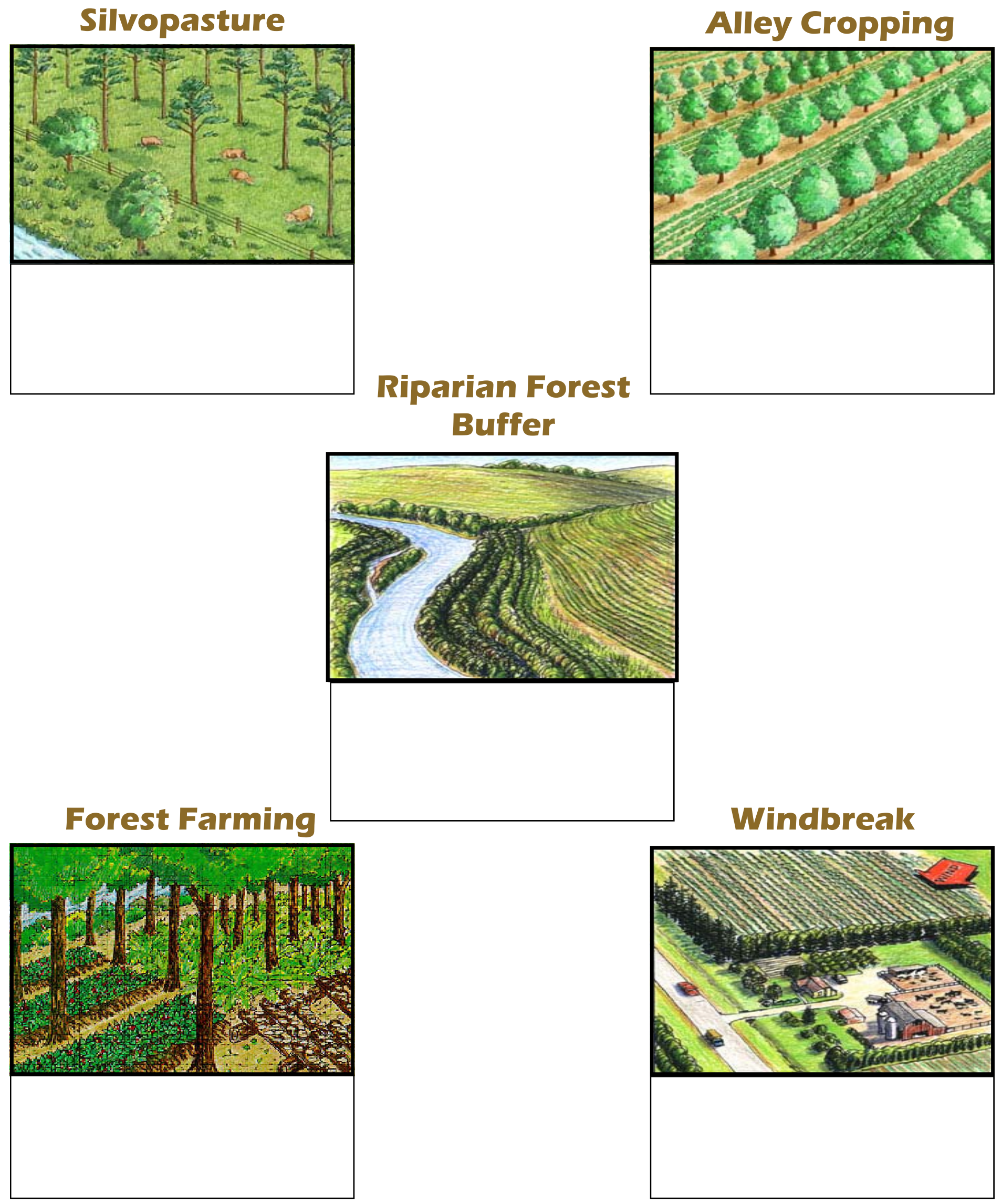


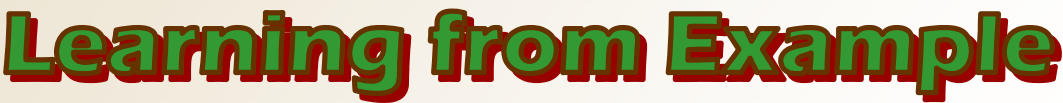

Activity 1.3

Learning Goal:

Youth will be able to analyze a situation to tell what was done correctly and what the landowner could do differently.

\section{Group Activity Instructions}

Analyze case studies about agroforestry.

- Make copies of Case Study \#1 (in Project Book) and Case Study \#2 (in Leader Guide). Make enough copies to give one case study to each team: half of groups receive Case \#1, half receive Case Study \#2.

- Make copies of discussion questions in Project Book, one copy per team OR each team can use one Project Book to obtain questions.

- Review introduction and activity in Project Book to facilitate activity.

- Divide youth in teams of 2 or 3 .

- Give each team: 1) one set of discussion questions 2) one case study.

- After completing activity, ask youth to work with their team to write discussion questions answers in shared Project Book to prepare for group discussion.

- Gather all youth and lead group discussion using discussion questions in Project Book. Be sure to distinguish two different Case Studies.

Mr. Gordon manages his land for oranges, cattle, timber, and hunting leases and he conducts agrotourism on his land for business. Mr. Gordon's land is near several Orlando developments. The pressure is greater every year to sell the farm land to developers. He wants to earn more money from his property so he is converting pasture to silvopasture to keep leasing property for cattle grazing while simultaneously growing timber. In the process of installing the silvopasture systems, cattle were removed from the pastures where slash pine trees were planted for five years.

Mr. Gordon encountered a few problems from changing over to agroforestry. The first planting of trees became infected with pitch canker. Mr. Gordon had to keep cattle off of the area where slash pine were planted for five years and therefore lost the income from leasing.

He also benefits in other ways from agroforestry. The protective tree cover provides benefits in the winter and summer. In the winter, the trees protect the grass from frost and extend the growing season of the pasture grasses. In the summer, the trees provide shade that helps reduce heat stress in the cattle. Also, Mr. Gordon sells a variety of forest products such as pine straw, as well as the hunting leases and tourism ventures.

Reading case studies like this one are beneficial in many fields of work including law and medicine. The reader can learn from others' mistakes and successes. In this case study, the most obvious preventable mistake is to buy "improved" pitch canker resistant slash pine seedlings, in order to minimize the number of trees that die. In addition, make sure to investigate the proper spacing for the species of tree that is planted. Mr. Gordon was smart to convert a "little at a time" over to agroforestry. This allows land owners to learn from experience and figure out the best method for their property.

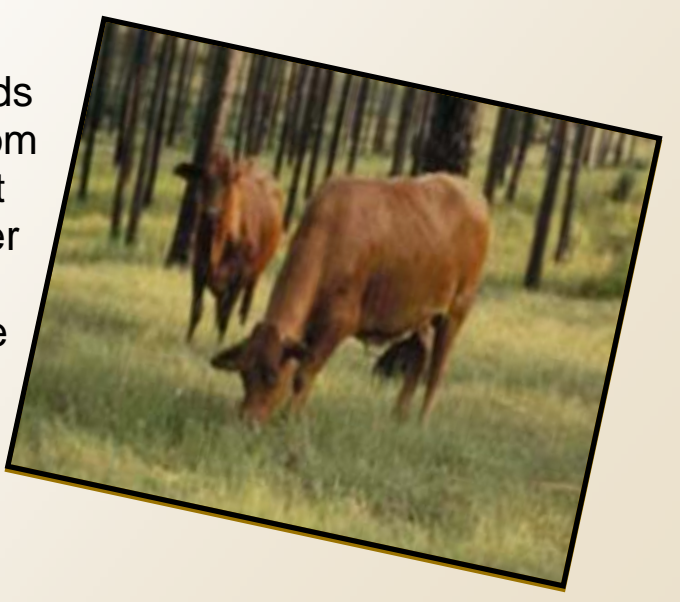




\section{Group Activity 1.3-Case Study \#2}

Many highly-valued medicinal, edible, and decorative plants grow best under partial shade. Forest farming, the cultivation of plants under a forest canopy, is an effective production method that provides multiple income opportunities. Canopy trees reduce costs by providing shade, moisture retention and protection, as well as production opportunities through timber, nuts or fruit, depending on the selected overstory species. Understory species such as ferns, camellias, or specialty mushrooms can provide high returns over regular, short-term intervals. Mr. and Mrs. Stokes' camellia nursery is a terrific example of one innovative landowner who is utilizing the economic benefits of forest farming to be competitive in a growing local market for ornamental plants, while improving wildlife habitat, aesthetic appeal, and recreational value all at the same time.

\section{OVERVIEW}

Amanda and Daniel Stokes currently own and manage the Shady Oak Nursery in Winter Springs, FL, which includes eleven acres of greenhouses, tree plantings, shaded camellia plantings, a small pond, and hedge rows. They grow specialty vegetables in the greenhouses, occasionally harvest trees, and grow tea bushes, but their most income comes from the camellias. As you tour the property, Mr. and Mrs. Stokes will point out beneficial lady bugs that are predators to aphids, (which can damage camellias), and ask you to observe how the oaks provide a natural shading, letting spots of light fall through the canopy at certain times throughout the day. More closely mimicking the native ecology of the area through these and other practices has created a lowinput technique for producing healthy, beautiful camellia plants. Cardinals, blue birds, and many other bird species, along with small mammals and reptiles take advantage of the abundant shelter, food, and water that the Stokes pride themselves in providing. Some of these species provide a service by gleaning harmful insects from the camellia crop. Separating stands of oaks or pine are rows of wax myrtle, huckleberry, blackberry, and many wildflower species. Aside from their aesthetic appeal, these strips of vegetation create windbreaks, protecting crops from wind damage, moderating temperature, and reducing drift of unwanted insects and chemicals from adjoining areas. They are also highly favored travel routes for wildlife.

\section{OBJECTIVES}

Mr. and Mrs. Stokes appreciate the pest control and shade that producing nursery plants under oak trees provides. They have reduced the costs associated with inputs, only having to spray a horticultural oil approximately three times a year. They use mostly compost in their soil, which provides the high organic content that camellias thrive on. Keeping their costs lower than producers who rely on shade cloth and frequent chemical applications has given the Stokes an economic competitive edge.

\section{CHALLENGES}

Insects can be a problem for nursery producers in this humid, subtropical climate. The species that cause the most problems will vary from year to year, but certain aphids and spider mites have been known to destroy their camellia crops.

\section{ECONOMICS}

The Stokes are experiencing great success with their potted camellias, green tea bushes, and other hedge species that he sells to landscapers and individuals. Due to their close proximity to the city of Orlando, which is one of the fastest growing areas in Florida, the Stokes expect their products to remain in high demand.

\section{FUTURE PLANS}

With demand currently exceeding supply, the Stokes recently bought an additional patch of land and plan to create the same oak - camellia systems in those areas.

Written by Nicole Strong 


\section{Group Activity 1.3 Discussion question answers to Case Study \#2}

The products in this system include: camellias, tea bushes, trees, and vegetables. Nothing was added or removed to create this forest farm practice.

Why did the land owner decide to manage the land as an agroforestry system?

The land owners decided to manage land as an agroforestry system because of the economic and environmental benefits. Mr. and Mrs. Stokes appreciate the pest control and shade that producing nursery plants under oak trees provides. They have reduced the costs associated with inputs, only having to spray a horticultural oil approximately three times a year. They use mostly compost in their soil, which provides the high organic content that camellias thrive on. Keeping their costs lower than producers who rely on shade cloth and frequent chemical applications has given the Stokes an economic competitive edge.

So far, there have been no problems associated with changing over to agroforestry. However, insects can be a problem. The species that cause the most problems will vary from year to year, but certain aphids and spider mites have been known to destroy a few camellia crops.

Studying case studies is used in the career of business management. When planning a new business, case studies of failed businesses can be analyzed to learn what not to do. Through reading a handful of case studies about businesses that failed, youth can determine their common trends and themes. These commonalities are what either needs to be avoided or strengthened when you start your own business. In addition, case studies are used in medicine, social work, and law.

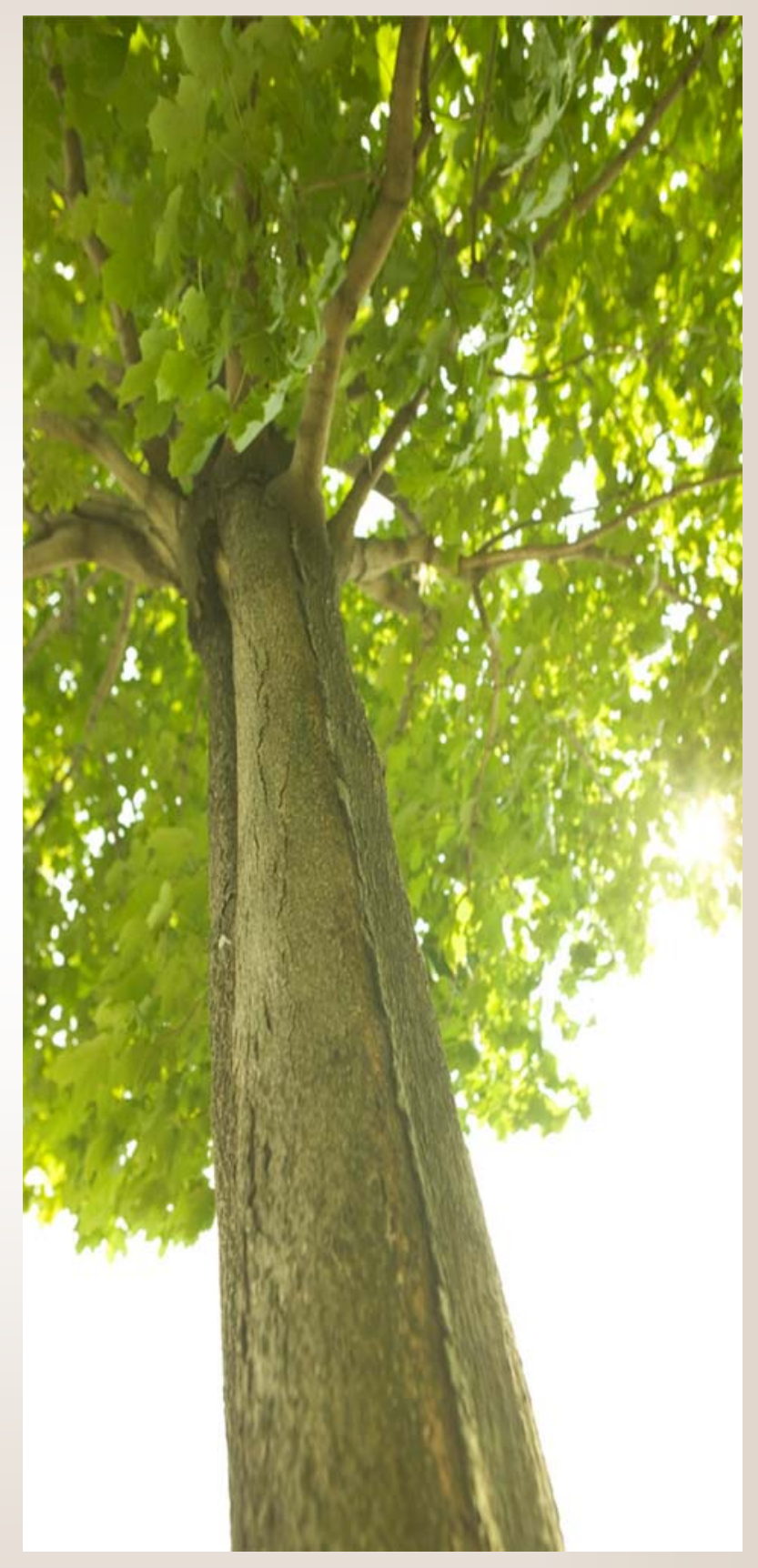




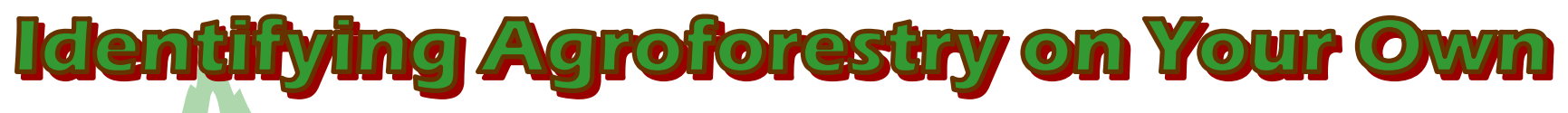

\section{Activity 1.4}

\section{Learning Goal:}

Youth will be able to find and identify each practice, list the specific products. benefits, and challenges of each practice.

\section{Group Activity Instructions}

Use Relay Game to see how much youth have learned as an introduction before this lesson topic.

Youth find and compile pictures of agroforestry in their community or on-line and communicate their finding.

- Make a plan to help youth find agroforestry. Contact your county extension agent to find out if there are agroforestry systems you can visit. Or offer website links listed in back of Leader Guide.

- Review introduction and activity in Project Book to facilitate activity.

- $\quad$ Divide youth in teams of 2 or 3.

- Each team will use one Project Book to work through activity together.

- Each team can decide how to divide up responsibility to complete activity. For example, some may put one person in charge of taking or finding pictures and other team members to do research to communicate their findings.

- After completing activity, ask youth to work with their team to write discussion questions answers in shared Project Book to prepare for group discussion.

- Gather all youth and lead a group discussion using discussion questions in Project Book (answers in Leader Guide).
This activity is aimed to help youth look at their own community to find agroforestry or discover examples in other places on their own. This will allow the youth to think more in depth about agroforestry systems and their functions. One important aspect of agroforestry is to see how the system will change over time. Agroforestry systems involve growing different species near each other. It is important for the land owner to always think about how each species will affect the other. For example, as trees grow older, they will produce more shade. What the land owner will be able to grow near or under the trees in year 2 will be different than in year 10 .

An important function of agroforestry is that it provides many environmental benefits for the community and state in which you live. Whether it's protecting drinking water, improving soil conditions, or diversifying income for the land owner, the record book can be used to help explain agroforestry and its benefits to others.

Pictures and examples are useful for explaining ideas that are new to others. Record books can be helpful in the field of agriculture, forestry, extension, or others where you need to spread knowledge. Scientists also use "field notebooks" to make a record of new ideas and useful information from others and to document discoveries made in the field. For many scientists, it is a standard practice to keep a field or record book.

It is hard to say if more land owners would use agroforestry if they knew about it. Any change of practice is resisted at first, unless there is evidence that the person that uses it will benefit more than what they were doing previously. If landowners heard about agroforestry from another land owner that had a successful agroforestry practice, then more people would likely try it. It also depends on the interests of the land owner. If the priorities of the land owner are to focus on agriculture sustainability and diversify products grown on the land, then agroforestry may be the perfect solution!

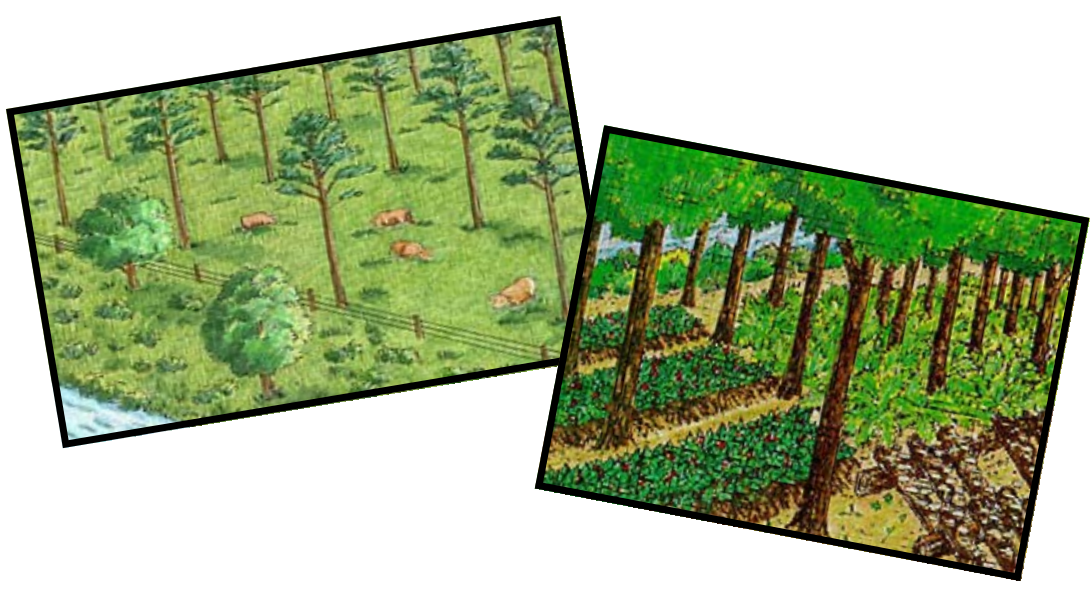




\section{Successful Silvopasture: A Relay Game}

Learning goal: Youth will be able to name three benefits of the agroforestry system silvopasture.

\section{Group Activity}

Life Skill:

Communicating and working as a team

Project Skill:

Youth can identify three benefits of silvopasture

\section{Background:}

Two common land management practices in Florida include pine plantations and pasture with cows. Pine plantations are characterised by same-aged pine trees grown in rows in order to harvest for pulp or lumber products. Pasture with cows is characterized as fields of grass with cattle grazing in order to raise and sell cattle. In this excersise, we will introduce a system for managing land called agroforestry. This system is thousands of years old and is currently used by people all over the world. The word agroforestry comes from its meaning. Agro-forestry is land management that adds trees to livestock operations or crop fields. Agroforestry takes advantage of the benefits that come from adding trees to these systems. Here in Florida, you can find landowners that grow trees with grass while grazing cattle underneath the trees on the same land. This is one type of agroforestry, called silvopasture. There are three main benefits of silvopasture. One is that the trees provide shade to the cattle. The second is that the cattle fertilize the trees. The third is that the trees absorb excess nutrients that would otherwise wash into the rivers and lakes and contaminate water quality.

\section{Advanced Preparation:}

Before youth arrive, set up game. Make starting line. Scatter agroforestry cards about 10 yards away from starting line. (farther if there is room)

\section{Introduction to Activity:}

Review the basic concepts of two separate systems: pine plantations and pasture with cows. Pass around some pictures of agroforestry in Africa, South America, Asia, and Florida. Ask youth what they think agroforestry means, by looking at the two part of the word, "agro" and "forestry." Define agroforestry. Next, explain that silvopasture is one type of agroforestry used in Florida. Define silvopasture and explain the three benefits of silvopasture.

Tell students they are going to play a relay game in which they are looking for the three benefits of silvopasture (or agroforestry). Divide the kids into groups of If uneven, one or two groups of 2 . Line up groups at the starting line.

\section{Materials:}

- Area, either indoors or outdoors, large enough for students to run.

- Laminated copies of agroforestry silvopasture square cards. Enough copies for each team to have one set of six (one page) each + a few pages extra.

- Pictures of agroforestry in Africa, Asia, Florida. Find on internet and print out with labels of where each picture is from.

- Duct tape or other marking for starting line.

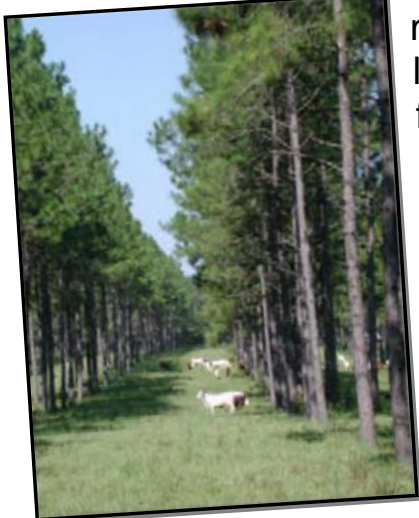

Tell the students they are landowners that want to earn the title of "agroforestry master" through knowledge of three of the benefits ofsilvopasture. There are at least three benefits of a silvopasture system. Ask them what are the three benefits they are looking for? Review the benefits.

Each relay team must find one of each benefit of a successful silvopasture system scattered on the ground 10 yards (or more) from the starting line. Only one person from each team can run at one time, relay style. Each team member can pick up only one benefit card at a time. You are not allowed to gather two cards in one run. If youth find at the end they have two of the same, they should run back to exchange it. Once the team has all three: "Trees provide SHADE for cattle," "Cows provide FERTILIZER for trees," and "Trees PROTECT the WATER and keep it clean," they should yell "agroforestry!" 
Trees provide SHADE for cattle

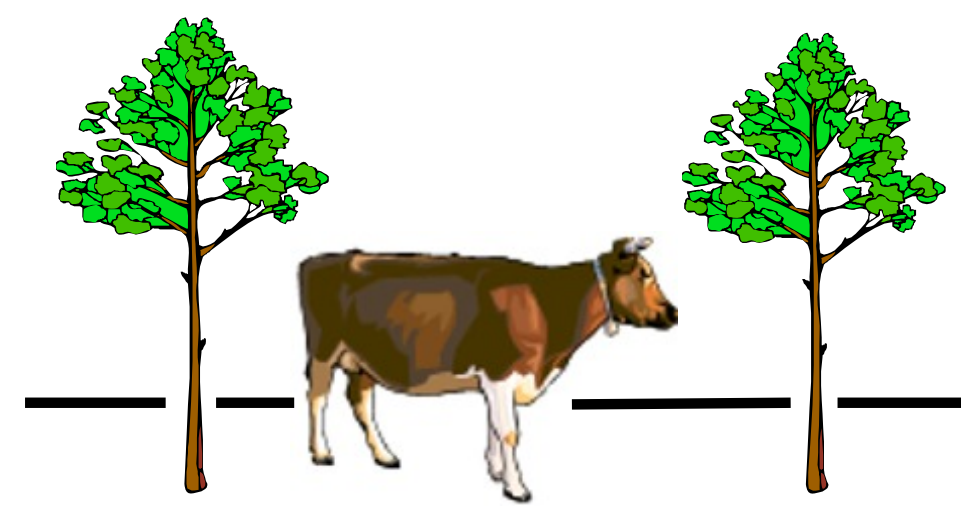

8x--

Cows provide FERTILIZER for trees

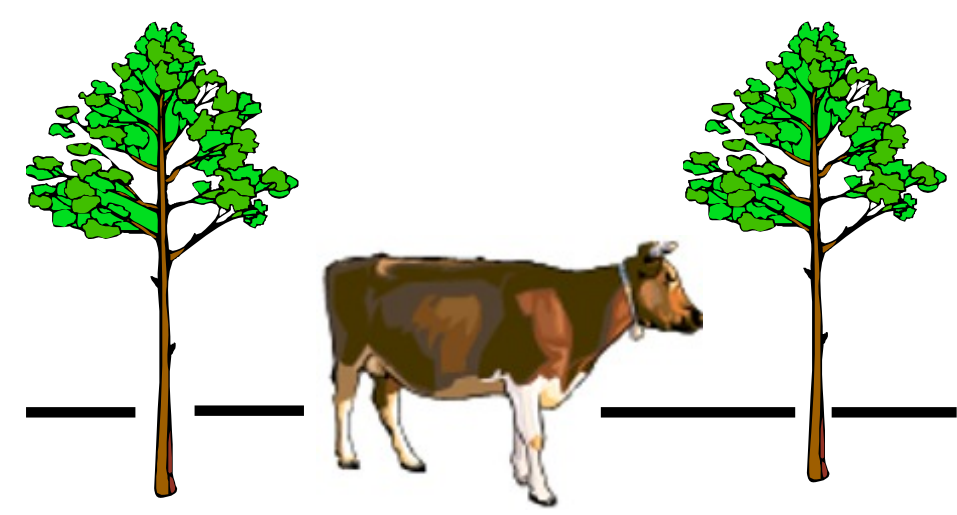

8

Trees PROTECT the WATER and keep it clean
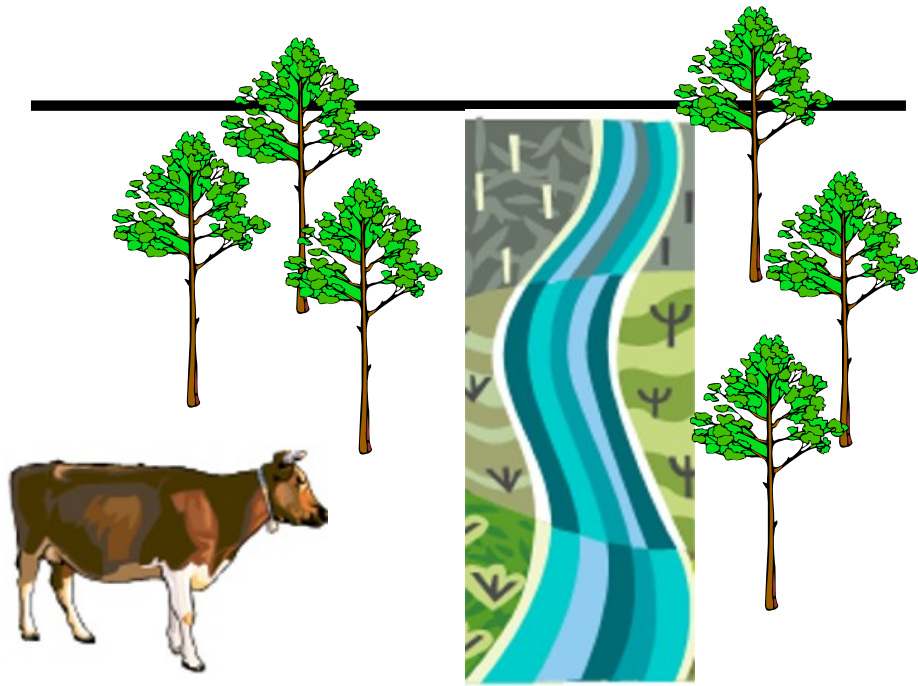

\section{Cattle Pasture}
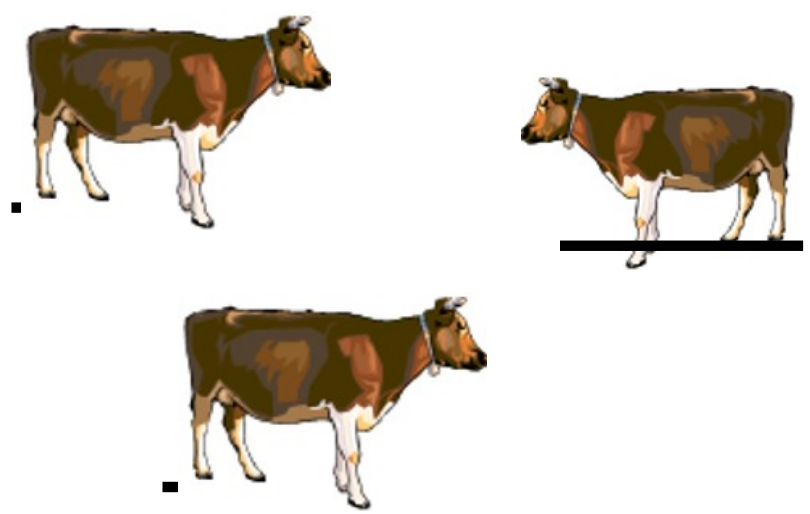

Pine Plantation
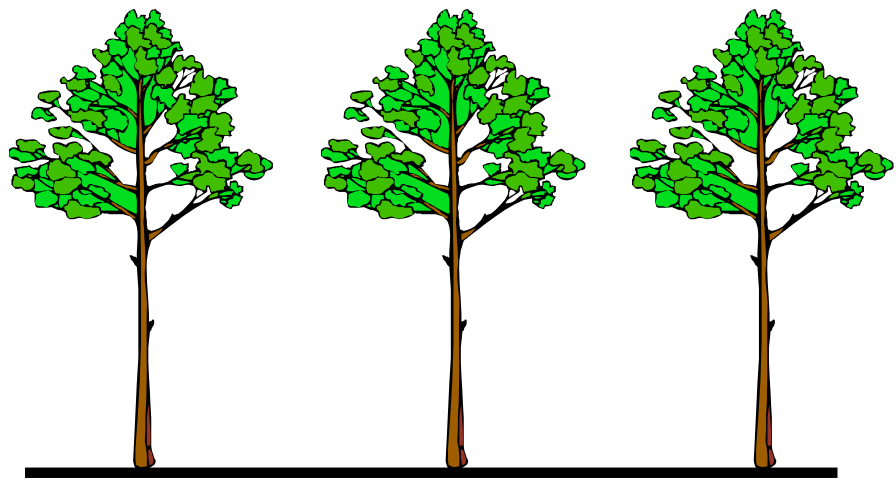

Fertilizer and cow waste run-off into the river
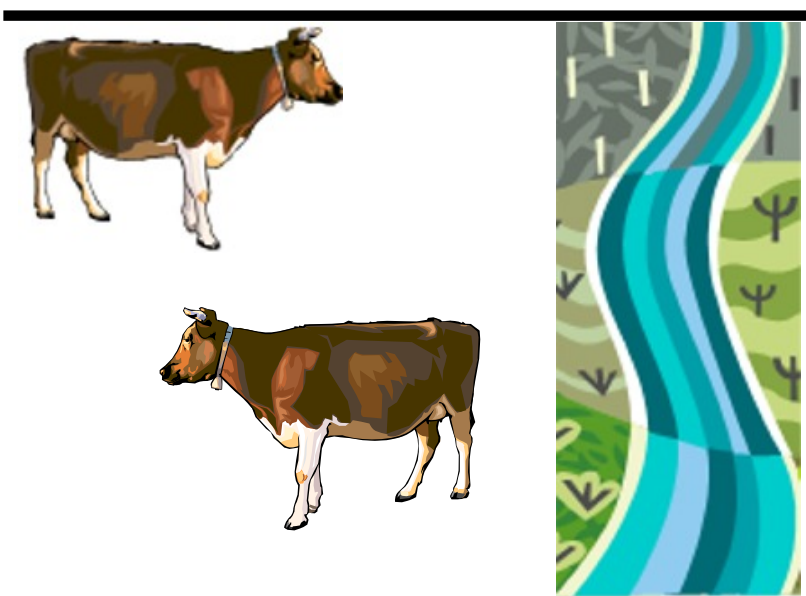


\section{Share with your helper}

\section{Discussion Questions}

- What are two things you must find in a silvopasture system?

- How did you work as a team?

\section{What's important?}

1. How do you think the sun affects cows in a pasture on a sunny day in July? How would they feel in a silvopasture system?

2. Trees grow faster with good nutrients in the soil, which is why we add fertilizer. Nutrients that are added little by little are better than nutrients that are added just once a year in a large amount. What service do cattle provide for the trees in a silvopasture system?

3. Where does the water go when it rains on a livestock pasture? What does the water run into as it travels across the surface of a pasture? When too many of these nutrients get into the water, what happens?

\section{What have you learned?}

1. Explain the technique your team used to make sure you ended up with all three silvopasture benefits?

2. Did you find communicating during the relay easy or difficult? Why?

\section{Imagine what's next!}

1. How would you improve your relay techniques if you played this game again?

2. When may you need to communicate important information in a fast paced or stressful situation?

\section{Discussion Points}

Two things you must find in a silvopasture system are: livestock (or otherwise cattle) and trees. These are the two things that you can remind the youth to look for on the cards. If they don't see BOTH cattle and trees on the SAME card, then that is NOT silvopasture.

A hot, sunny day in the middle of pasture in July is stressful for a cow. Cattle prefer to graze in the shade of trees, such as in a silvopasture system. This reduces heat stress and keeps cattle in better health.

Trees grow faster with good nutrients in the soil, which is why we add fertilizer. Nutrients that are added little by little are better than nutrients that are added just once a year in a large amount. Cattle provide this service of adding small amounts of fertilizer in frequent intervals.

When it rains, the water flows over the land and takes particles and nutrients with it. In cow pastures, this means excess fertilizers and cow waste. Too many nutrients in the water causes poor water quality, which can cause fish to die or bad drinking water for us! When we add trees in the cow pasture and along the banks of the river, lake, or other bodies of water on the land where cattle graze, the trees and other vegetation absorb more of the nutrients before they get washed into the river.

Teams may have different strategies to find all three cards in only three trips. Some may assign the card they are looking for ahead of time. Some teams may assign the first person on the relay to keep tract. For example, s/he may come back with the "Fertilizer" card and tell the next person, "Find the "Protect the Water" or "Shade" card!" Some teams may be fast runners and end up winning from simply running back and forth until they come up with the correct three.

The ability to communicate in a fast paced or stressful situation is important in many situations. When a friend or family member gets injured, youth must think fast and make a smart decision on how to take action. Some jobs require fast decision making. Construction managers, doctors, lawyers, and those involved in sales are just some of the people that must think quickly on their feet. The skill of making smart decisions for a group in a short amount of time is a skill youth can use throughout their life. 


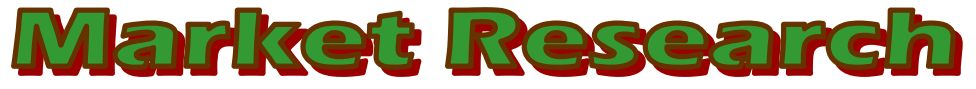

This activity gives youth the experience of gathering information from an audience they are interested in understanding. Youth can gather information on what product would sell the best in order to decide what agroforestry products to grow. They can conduct a survey of those that will be purchasing the products. Whether it is a restaurant, store, or buyers at the farmer's market, these purchasers can provide helpful answers.

In this exercise, the people that come to the farmer's market are the purchasers. You may find that people come to the farmers market for a variety of reasons. Some of those reasons include: to support their community farmer's, to buy fresh fruits and vegetables, and to see and spend time with community members.

Certain products sell better than others. Factors that drive a product to sell well can include: good price, nice appearance, or freshness. Products may not sell well because every farmer at the market sells that same product and there is too much supply. Maybe the product is overpriced. Even though the product may be fresher and more delicious than what you can buy at the supermarket, if the farmer's market product is considerably more expensive, this may deter people from buying it.

Products that you would want to sell are those that the sellers at the farmer's market run out of first. This means they are in high demand and the buyers that come to the market late may want to buy this product also. You may also want to grow products that the buyers wish were at the market. This is a "gap" in the market that can be filled.

There are ways farmers can attract people to their stand to buy their products. A colorful sign to attract people to the product, where samples are available is a great way to start. Offering recipes for the food products can help those that don't know what to do with one of the food items. Farmers also add value to their products by making vegetables "ready to eat" (i.e. washing and chopping up lettuce and spinach in a bag to buy) or making berries into jelly or jam.

The skill of conducting a survey can be used to improve service-related products. Enjoyment of an art fair, satisfaction of eating at a restaurant, or services needed at a resort are all examples of where a survey may be appropriate to make things better.

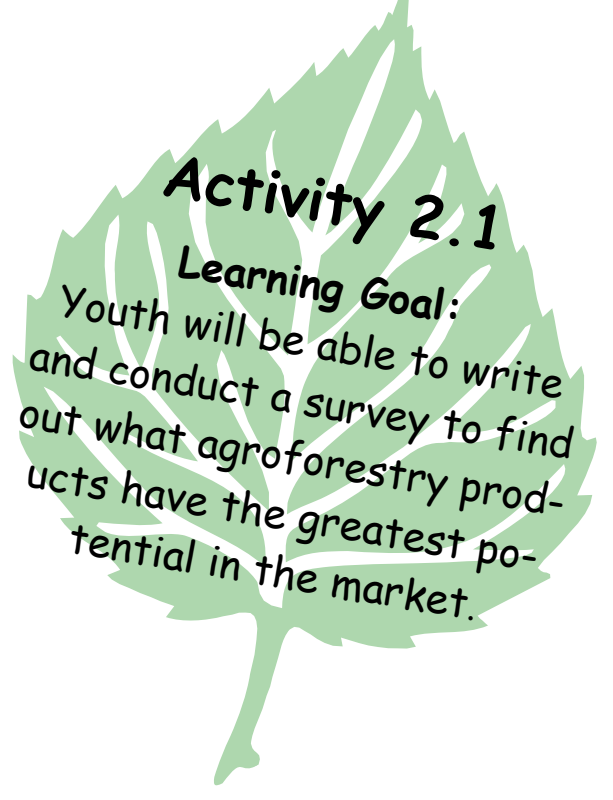

\section{Group Activity Instructions}

Field trip to local farmer's market to conduct survey. *

- Review introduction and activity in Project Book to facilitate activity.

- Divide youth in teams of 2 to 4 .

- Each team needs one Project Book to work through activity together.

- Divide team in half: one half will conduct survey with farmers, other half with buyers.

- After completing activity, ask youth to work with their team to write discussion question answers in shared Project Book to prepare for group discussion

- Gather all youth and ask each team to share two of their most favorite or interesting answers to survey with entire group.

- Lead group discussion using discussion questions in Project Book (answers in Leader Guide).

Note: This lesson may need to be done in two meetings/sessions. One to help youth prepare interview questions and the second is their field trip to market location. 
Activity 2.2 Learning Goal: Youth will be able to calculate and compare the budget of three land management systems.

\section{Silvopasture System}

\begin{tabular}{|l|l|c|c|}
\hline \multicolumn{1}{|c|}{ Year } & \multicolumn{1}{|c|}{ Activity } & Cost \$/acre & Revenue \$/acre \\
\hline 0 & Establishment of trees \& forage & 250 & \\
\hline $1-20$ (annual) & Forage maintenance & 30 & \\
\hline $4-15$ (annual) & Cattle purchase/care \& sales & 350 & 510 \\
\hline 15 & Thinning trees & & 200 \\
\hline $4,8,12,16,20$ & Prescribed burn & & 15 \\
\hline 20 & Final harvest & 10 & \\
\hline $0-20$ (annual) & Property tax & & \\
\hline
\end{tabular}

2. Cattle Pasture System

\begin{tabular}{|l|l|l|l|}
\hline Year & Activity & Cost \$/acre & Revenue \$/acre \\
\hline 0 & Establishment of forage & 115 & \\
\hline $1-20$ (annual) & Forage maintenance & 30 & \\
\hline $2-20$ (annual) & Cattle purchase/care \& sales & 350 & 525 \\
\hline $\begin{array}{l}2,4,6,8,10,12, \\
14,16,18,20\end{array}$ & Prescribed burn & 5 & \\
\hline $0-20$ (annual) & Property tax & 10 & \\
\hline
\end{tabular}

\section{Pine Plantation System}

\begin{tabular}{|l|l|l|l|}
\hline Year & Activity & Cost \$/acre & Revenue \$/acre \\
\hline 0 & Establishment of trees & 200 & \\
\hline $10-20$ (annual) & Hunting lease & & 10 \\
\hline $8,9,10,11,12$ & Pine straw & & 70 \\
\hline 15 & Thinning trees & & 500 \\
\hline $4,8,12,16,20$ & Prescribed burn & 15 & \\
\hline 10,15 & Fertilization & 80 & \\
\hline 20 & Final harvest & & 2000 \\
\hline $0-20$ (annual) & Property tax & 10 & \\
\hline
\end{tabular}




\section{Silvopasture System}

\begin{tabular}{|l|l|l|l|}
\hline Year & Costs \$/ac & Revenue \$/acre & Net profit \$/acre \\
\hline $\mathbf{1}$ & $250+30+10=290$ & & -290 \\
\hline $\mathbf{2}$ & $30+10=40$ & & -40 \\
\hline $\mathbf{3}$ & $30+10=40$ & & -40 \\
\hline $\mathbf{4}$ & $30+350+15+10=405$ & 510 & 105 \\
\hline $\mathbf{5}$ & $30+350+10=390$ & 510 & 120 \\
\hline $\mathbf{6}$ & $30+350+10=390$ & 510 & 120 \\
\hline $\mathbf{7}$ & $30+350+10=390$ & 510 & 120 \\
\hline $\mathbf{8}$ & $30+350+15+10=405$ & 510 & 105 \\
\hline $\mathbf{9}$ & $30+350+10=390$ & 510 & 120 \\
\hline $\mathbf{1 0}$ & $30+350+10=390$ & 510 & 120 \\
\hline $\mathbf{1 1}$ & $30+350+10=390$ & 510 & 120 \\
\hline $\mathbf{1 2}$ & $30+350+15+10=405$ & 510 & 105 \\
\hline $\mathbf{1 3}$ & $30+350+10=390$ & 510 & 120 \\
\hline $\mathbf{1 4}$ & $30+350+10=390$ & 510 & 120 \\
\hline $\mathbf{1 5}$ & $30+350+10=390$ & $510+200=710$ & 320 \\
\hline $\mathbf{1 6}$ & $30+15+10=55$ & & -55 \\
\hline $\mathbf{1 7}$ & $30+10=40$ & & -40 \\
\hline $\mathbf{1 8}$ & $30+10=40$ & & -40 \\
\hline $\mathbf{1 9}$ & $30+10=40$ & 1000 & -40 \\
\hline $\mathbf{2 0}$ & $30+15+10=55$ & & 945 \\
\hline
\end{tabular}

\section{Cattle Pasture System}

\begin{tabular}{|l|l|l|l|}
\hline Year & Costs \$lac & Revenue \$/acre & Net profit \$lacre \\
\hline $\mathbf{1}$ & $115+30+10=155$ & & -155 \\
\hline $\mathbf{2}$ & $30+350+5+10=395$ & 525 & 130 \\
\hline $\mathbf{3}$ & $30+350+10=390$ & 525 & 135 \\
\hline $\mathbf{4}$ & $30+350+5+10=395$ & 525 & 130 \\
\hline $\mathbf{5}$ & $30+350+10=390$ & 525 & 135 \\
\hline $\mathbf{6}$ & $30+350+5+10=395$ & 525 & 130 \\
\hline $\mathbf{7}$ & $30+350+10=390$ & 525 & 135 \\
\hline $\mathbf{8}$ & $30+350+5+10=395$ & 525 & 130 \\
\hline $\mathbf{9}$ & $30+350+10=390$ & 525 & 135 \\
\hline $\mathbf{1 0}$ & $30+350+5+10=395$ & 525 & 130 \\
\hline $\mathbf{1 1}$ & $30+350+10=390$ & 525 & 135 \\
\hline $\mathbf{1 2}$ & $30+350+5+10=395$ & 525 & 130 \\
\hline $\mathbf{1 3}$ & $30+350+10=390$ & 525 & 135 \\
\hline $\mathbf{1 4}$ & $30+350+5+10=395$ & 525 & 130 \\
\hline $\mathbf{1 5}$ & $30+350+10=390$ & 525 & 135 \\
\hline $\mathbf{1 6}$ & $30+350+5+10=395$ & 525 & 130 \\
\hline $\mathbf{1 7}$ & $30+350+10=390$ & 525 & 135 \\
\hline $\mathbf{1 8}$ & $30+350+5+10=395$ & 525 & 130 \\
\hline $\mathbf{1 9}$ & $30+350+10=390$ & 525 & 135 \\
\hline $\mathbf{2 0}$ & $30+350+5+10=395$ & 525 & 130 \\
\hline
\end{tabular}




\section{Pine Plantation System}

\begin{tabular}{|l|l|l|l|}
\hline Year & Costs \$lacre & Revenue \$lacre & Net profit \$lacre \\
\hline $\mathbf{1}$ & $200+10=210$ & & -210 \\
\hline $\mathbf{2}$ & 10 & & -10 \\
\hline $\mathbf{3}$ & 10 & & -10 \\
\hline $\mathbf{4}$ & $15+10=25$ & & -25 \\
\hline $\mathbf{5}$ & 10 & & -10 \\
\hline $\mathbf{6}$ & 10 & & -10 \\
\hline $\mathbf{7}$ & 10 & & -10 \\
\hline $\mathbf{8}$ & $15+10=25$ & 70 & 45 \\
\hline $\mathbf{9}$ & 10 & 70 & 60 \\
\hline $\mathbf{1 0}$ & $80+10=90$ & $10+70=80$ & -10 \\
\hline $\mathbf{1 1}$ & 10 & $10+70=80$ & 70 \\
\hline $\mathbf{1 2}$ & $15+10=25$ & $10+70=80$ & 55 \\
\hline $\mathbf{1 3}$ & 10 & 10 & 0 \\
\hline $\mathbf{1 4}$ & 10 & 10 & 0 \\
\hline $\mathbf{1 5}$ & $80+10=90$ & $10+500=510$ & 420 \\
\hline $\mathbf{1 6}$ & $15+10=25$ & 10 & -15 \\
\hline $\mathbf{1 7}$ & 10 & 10 & 0 \\
\hline $\mathbf{1 8}$ & 10 & 10 & 0 \\
\hline $\mathbf{1 9}$ & 10 & 10 & 0 \\
\hline $\mathbf{2 0}$ & $15+10=25$ & $10+2000=2010$ & 1985 \\
\hline & & & \\
\hline
\end{tabular}

\section{Summary}

\begin{tabular}{|l|l|l|l|}
\hline Years & $\begin{array}{l}\text { Silvopasture } \\
\text { Net profit \$/acre }\end{array}$ & $\begin{array}{l}\text { Cattle Pasture } \\
\text { Net profit \$/acre }\end{array}$ & $\begin{array}{l}\text { Pine Plantation } \\
\text { Net profit \$/acre }\end{array}$ \\
\hline $0-5$ & -145 & 375 & -265 \\
\hline $6-10$ & 585 & 660 & 75 \\
\hline $7-15$ & 785 & 665 & 545 \\
\hline $16-20$ & 770 & 660 & 1,970 \\
\hline $0-20$ & 1,995 & 2,360 & 2,325 \\
\hline
\end{tabular}




\section{How Would the Budget Change If:}

1) In year eight and on, the state passed a regulation that allows farmers to sell environmentally friendly meat for extra money. All farms with silvopasture (table 1) will increase the cattle sales by $\$ 75$ per acre.

12 years * $\$ 75=\$ 900$ more per acre

New Silvopasture Net Profit $=\$ 900+\$ 1,995=\$ 2,895$

2) In year five and on, the state passed a regulation that gives a tax break on cattle farms that practice environmentally friendly management. All livestock farms managing silvopasture (table 1) reduce property tax from $\$ 10$ to $\$ 5$ an acre.

(3 years to establish trees) 16 years * $\$ 5.00=\$ 80.00$ more per acre

New Silvopasture Net Profit $=\$ 80+\$ 1,995=2,075$

In any business there are costs and benefits. Costs can be defined as what the investor has to pay into the operation or anything that causes negative effects on health to humans. Often in order to keep production high, the land owner uses chemicals that can pollute the environment. Luckily, the land can handle certain levels of pollution without having a negative effect on living organisms. Agroforestry attempts to minimize health related costs involved in agriculture, animal raising, and forestry operations.

\section{Discussion Question Clues}

As with any investment, it is important to plan ahead. Budgets can help a person find out how much money they will need to invest. They can also determine when they will start making money from the operation. This budget shows that cattle pasture makes the most money from 0 through 5 years, while silvopasture requires the most investment.

No matter how thorough the budget, it is easy to leave out additional costs. In these land management systems, there are additional costs. When raising cattle, there are health issues that must be dealt with, including shots and care for sick animals. Feed will need to be purchased when the pasture does not grow in the winter. In a pine plantation and silvopasture, there is the risk of beetle infestation or damage from storms and hurricanes.

Costs also involve environmental hazards. When raising cattle on pasture land, there is the issue of waste runoff in the water. This can cause contamination of drinking water. Two of the factors that have the most influence on water quality include fertilizer and waste from cows. The system that protects water quality is the one that uses the proper amount of fertilizer, has the least amount of cow waste, and has buffers protecting all water ways. A tree plantation system that does not over fertilize runs the least risk of contaminating water. However, any of these three systems can protect water quality by installation of riparian forest buffers along water ways.

In order to make silvopasture more profitable, make sure to take advantage of all tax credits or increased selling rates from the product entitled for land owners managing an environmentally friendly practice. In addition, more products could be harvested from the land, such as pine needles for mulch, or selling hunting leases.

When youth plan a budget in advance, they may think of things they did not think of before. Youth can make a timeline of when they will need to order, buy, and plan for other services. The youth can also make a budget to plan for a field trip to learn about something new. The budget can help show how much money each student will need on the trip. Then they can figure out how much money each student will need to bring or raise in order to go on the trip. 


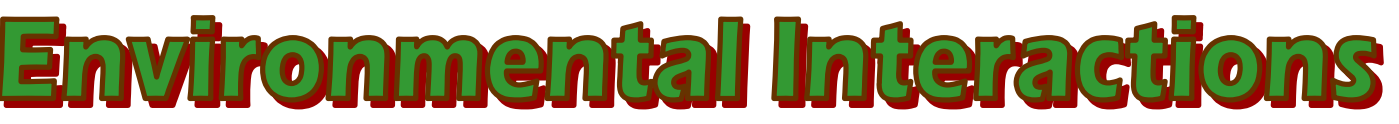

\section{Activity 2.3 \\ Learning Goal:}

Youth will be able to find and identify each practice, list the specific products. benefits, and challenges of each practice.

\section{Group Activity Instructions}

Play board game.

- Review introduction and activity in Project Book to facilitate activity.

- Divide youth in teams of 3 or 4 .

- Make sure each team has one game board (in Project Book), game pieces (different coins), set of game cards, paper to keep track of credit points, and pencil or pen. One pre-made, full set of game cards is available in back of the Leader Guide.

- Either ask youth to read game instructions on their own or you can explain the rules to the group provided in Project Book.

- After finishing game, lead group discussion using discussion questions in Project Book

- Ask youth to write the discussion questions answers in their Project Book after group discussion.
The same biological factors that can make agroforestry beneficial may also cause problems. It depends on proper placement and choice of species. Some biological factors that the agroforester must be careful about are underground competition between roots for water and nutrients; competition for light, especially as trees get larger and create more shade; and variation of fertilizer requirements for different crops. These interactions are important for the farmer to know about so that they can select species of plants and animals that will grow successfully together in an agroforestry system.

The climate, soil conditions, and other environmental conditions in your area will determine what the most important interactions in your area will be. For example, if you live where the summer sun is intense, shade may be the most important for grazing animals. If you live where there are strong winds, windbreaks may be the most important to protect animals and other crops. If you live where most of the land owners raise cattle, protecting the water with riparian forest buffers may be important.

Most of the "con" cards are due to mismanagement or poor planning. Most of these examples can be prevented; however, some are "acts of nature." It is important to talk with the county extension agent about how to plan the proper spacing for trees and crops. It is important to know how long to keep animals out of the area where tree seedlings are being established in a silvopasture system.

Biological interactions between plants and/or plants and animals are important beyond agroforestry. Many people have personal or community gardens where they grow fruits, vegetables, and other foods.

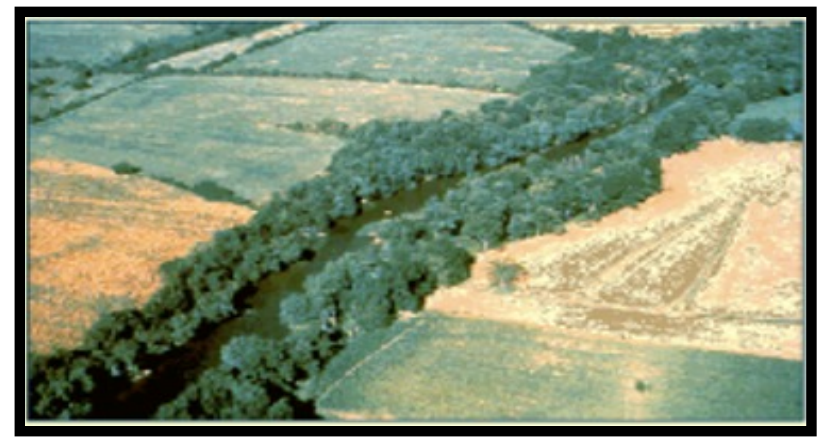

Strategic placement of plants can help keep insect pests and diseases out of the garden. When landscaping in an urban setting, the landscape architect or gardener must think about the requirements for each plant such as light and water. Along with effects or limitations of space, utility or sewer lines, competition between plants is an important factor when selecting plants for landscaping. Non-native plants can be a problem as they may be aggressive and take all the nutrients, water or sunlight for themselves, killing other plants in the same area. More information on exotic invasive plants can be found at the website of the Florida Exotic Pest Plant Council: http://www.fleppc.org/.

Trees provide many benefits in an urban setting. They provide shade which reduces the electric bill in the hot summer months. They provide habitat for birds and other tree dwelling animals. Trees can absorb water when there is a large rain storm. Trees provide shelter from the wind and heavy rain. In each city, there are urban foresters that keep track of the health and growth of trees on city property. It is their job to make sure the trees are trimmed so that they do not interfere with electric lines or pose hazards to people who walk beneath their canopies. 


\section{Plan a Site}

\section{Group Activity Instructions}

- Review introduction and activity in Project Book to facilitate activity.

- Divide youth in teams of 2 or 3.

- Each team will use one Project Book to work through activity together.

- Ask youth to work with their team to write discussion questions answers in shared Project Book to prepare for group discussion.

- Gather all youth and ask each team to present and explain their management plan.

- Lead group discussion using discussion questions in Project Book (answers in Leader Guide).

Just as we discussed in the budget section, it is important to plan ahead. When you make a management plan, you may be able to work out problems before actually encountering them.

There is flexibility when designing a diagram or map. Overall, make sure that it is clear what the diagram or map represents as a whole. The only requirement is that it is easy to read.

A few things to look for:

- Title

- Name and representing organization

- Each component in the diagram or map is represented in the key

- Compass

- Exciting colors

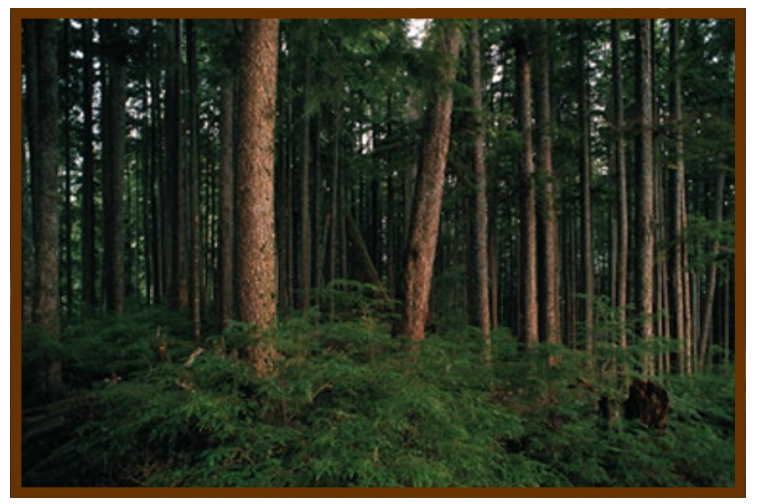

As we learned in previous sections, the land owner should do some research before starting a new agroforestry practice. When designing and implementing any of the five Agroforestry practices, it is important to consider the compatibility of the species with the site, the compatibility between species, the farm equipment available, and the potential markets.

Management plans need to be flexible. There is always the chance that something will happen out of the ordinary. When planning agroforestry management, it is important that the land owner expects and plans for change. The conditions will change as the trees grow taller and eventually are harvested.

Diagrams or maps are used when a driver is transporting goods, an architect is designing a building, a horticulturist is planning a garden, a clothes designer is creating a dress, or an engineer is planning a sewage system.

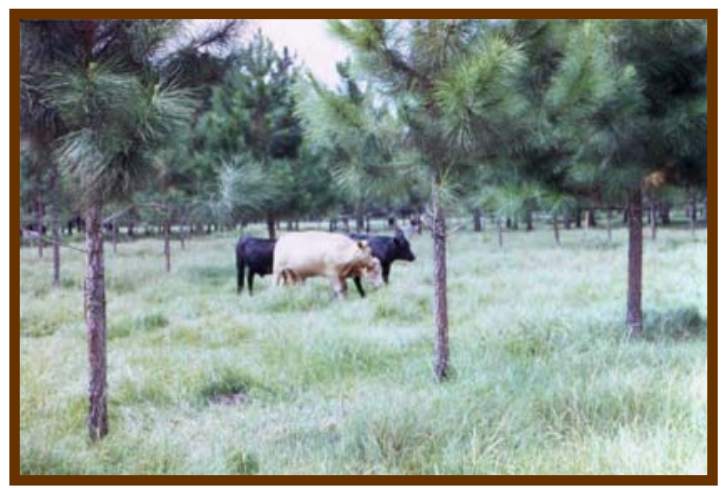


Activity 3.2

Learning Goal:

Youth will be able to create a public education campaign tool about agroforestry.

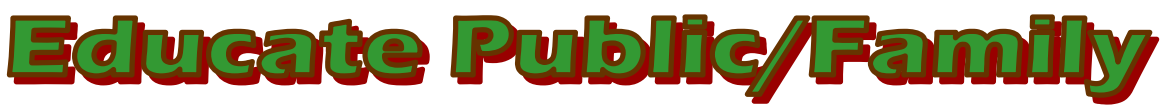

\section{Group Activity Instructions}

- Review introduction and activity in Project Book to facilitate activity.

- Divide youth in teams of 2 or 3.

- Each team will use one Project Book to work through activity together.

- Ask youth to work with their team to write discussion questions answers in shared Project Book to prepare for group discussion.

- Gather all youth and ask each team to present and explain their educational material.

- Lead group discussion using discussion questions in Project Book (answers in Leader Guide).

First it is important to think about which group of people the youth want to teach about agroforestry. This could be a group of farmers, community members, or other youth. Then they must decide where it is most convenient to talk to these people and the method of distributing information.

Conveying each form of information has its own advantages. A poster is easy to make; the youth can place it is public areas where they have permission and a wide audience will be able to look at it. Posters may work well at the grocery store, a fair, or the farmer's market. A brochure is excellent because people can take it with them to look at it later. They can distribute brochures in neighborhoods, or have them available to take home in addition to a poster presentation in a public area. A presentation is useful when you can hold the attention of a group, such as at a meeting.

In this activity, the youth play the role of an extension agent. Without the help of community members, it is mostly up to extension agents to share useful information between land owners. Land owners are busy people and may not always be able to talk to each other. Extension agents can keep the land owners connected by sharing information in a timely manner, so that different land owners do not make the same mistake or can heed a warning about an insect infestation or other problem. Extension agents can also play the role of organizing meetings for land owners to discuss common concerns and successes.
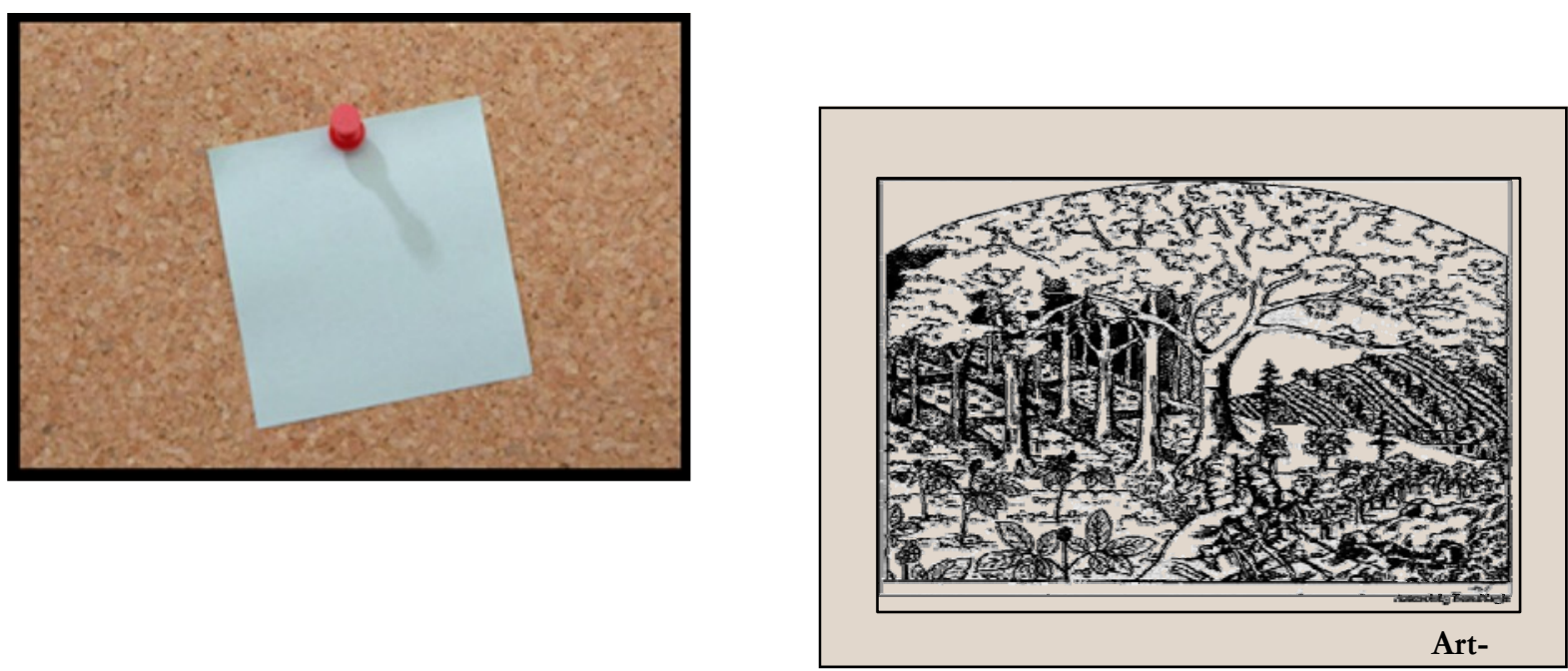


\section{Agroforestry Quiz Bowl}

Prepare questions and answers by asking youth to write two or three. They can use their agroforestry knowledge that they have gained through working the activities in the Project Book or do research.

To play you will need two or more teams of two to four members per team, a moderator to ask questions and indicate who should answer the question, a judge to indicate correctness of the response, and a scorekeeper. Rotate positions so everyone can be involved and develop important skills. Follow the quiz bowl with a discussion about how the quiz bowl was conducted and what was learned about agroforestry, leadership and teamwork.

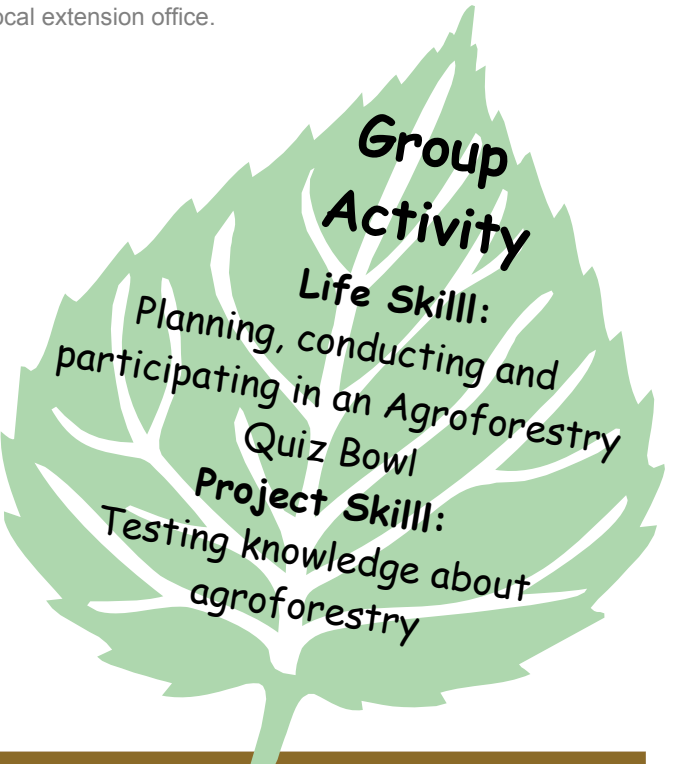

\section{Sample Quiz Bowl Questions}

Q. Name the agroforestry system that combines trees with pasture and livestock on the same land.

A. Silvopasture

Q. Name the agroforestry systems where strips of trees and shrubs are grown and managed for products along a body of water.

A. Riparian forest buffer

Q. Name the agroforestry system where trees and shrubs are grown for products and protect crops, animals, and people from wind, sun, and soil erosion.

A. Windbreak

Q. Name the agroforestry practice where crops are grown under the canopy of a shady forest.

A. Forest farming

Q. Name the agroforestry practice where crops are grown in between widely spaced trees or shrubs.

A. Alley cropping
Q. Name a product you can harvest or a plant or shrub you can grow in a forest farming system.

A. (Any of the following) Nuts, fruits, berries, mushrooms, ferns, ornamentals, honey, medicinal plants

Q. Name two products that come out of a silvopasture system.

A. Trees/lumber and livestock (cows, goats, etc.)

Q. Name an environmental benefit of agroforestry.

A. (Any of the following) Protection of water quality, enhanced soil fertility, erosion control.

Q. Name a benefit that silvopasture provides for the land owner.

A. More than one source of income for the farmer: $\$$ from both live stock and trees. OR Maintains health of livestock by protection from hot summer sun.

Q. Name a benefit that alley cropping provides for the land owner.

A. Harvest several products at different times during the year.
Q. Name a benefit that forest farming provides for the land owner.

A. Additional use of land or growing products under a forest canopy for extra income.

Q. How do trees, shrubs and other plants protect water quality in a riparian forest buffer?

A. The roots absorb excess fertilizers passing through the soil before washing into the water.

Q. What happens when trees and crops are planted too close together?

A. They compete for nutrients

Q. In order to grow plants under a forest canopy, they must be tolerant of ?

A. Shade

Q. If you want to protect water quality of a lake on your property, you could install this type of agroforestry system.

A. Riparian forest buffer 


\section{Quiz BowI Discussion Questions}

Share with your helper

- How did you organize the Agroforestry Quiz Bowl?

- How did you get the questions? Decide on the rules?

\section{What's important?}

1. What were some of the challenges you faced while organizing the quiz bowl?

2. What did you learn about your knowledge of agroforestry?

\section{What have you learned?}

How did organizing this activity compare to other activities you have organized?

\section{Imagine what's next!}

What would you do differently next time when organizing an activity?

\section{Discussion Points}

There are no right or wrong answers to this set of discussion questions. Asking youth to write questions and answers for the quiz bowl should help them realize how much they have learned about agroforestry. They should be able to come up with some questions on their own and discover more about agroforestry by doing a little research. It is fun to see what the youth come up with to challenge each other.

You understand as the leader, organizing activities takes practice. Ask youth what went wrong during the quiz bowl and how they think they can avoid the same problem next time. Emphasize the importance of planning. Youth may have helped organized a friend's birthday party, family event, or planned what to eat for dinner.

\section{Job Opportunities for Activity Skills:}

\section{4: Job that uses record book}

Record books are used by Journalists. Journalists keep a notebook to keep tract of the story they are investigating. They fill the notebook with interviews, facts, thoughts, and any details they may want to use in the articles. People now create online record books, or journals. You can create your own at: http://www.livejournal.com/

\section{1: Market research}

How did you decide which cell phone to buy? You most likely compared companies and brands, which is market research. Market research requires the skill of conducting surveys to find out important information from buyers.

Marketing managers use the results from surveys and work with advertising and product promotion managers to promote the company's products and services and to attract potential users. For more information on market careers, visit http://www.marketresearchcareers.com/

\section{2: Budgeting:}

Do you like working with numbers, organizing, and planning? Budget analysts work for companies, large and small to examine their budgets for completeness, accuracy, and compliance with the law. Budget analysts keep track of the company's money and makes sure the company is running well. For more information about budget analysts, visit http://www.careerplanner.com/JobDescriptions/Budget-Analysts.cfm.

\section{3: Job that studies the biological interactions:}

\section{Biological scientist}

Do you want to defend and care for the environment through your career? Some biological research scientists study how plant and animal interactions affect the functions of ecosystems. Their scientific research findings are used as evidence in the court of law to explain why or why not a certain animal, plant, or habitat needs to be protected.

\section{1: Plan a site}

\section{Landscape Architect:}

For every architect that designed a building, there is a landscape architect that designs the area outside the building. Landscape architects design outdoor areas so that they functional, beautiful, and compatible with the natural environment. They plan the location of buildings, roads, and walkways, and the arrangement of flowers, shrubs, and trees. Find more about landscape architects at:http://www.bls.gov/oco/ocos039.htm OR

http://www.career.edu.my/path/desc.asp?career id=73 


\section{Alley Cropping Cards - Brown}

\begin{tabular}{|c|c|c|c|}
\hline 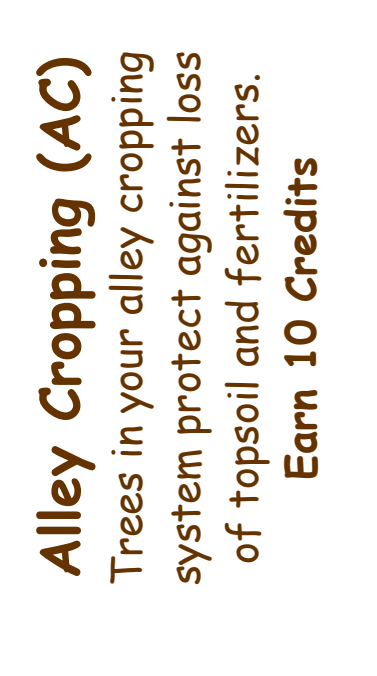 & 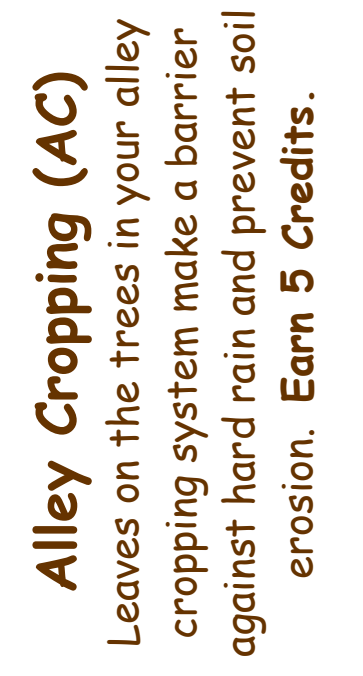 & 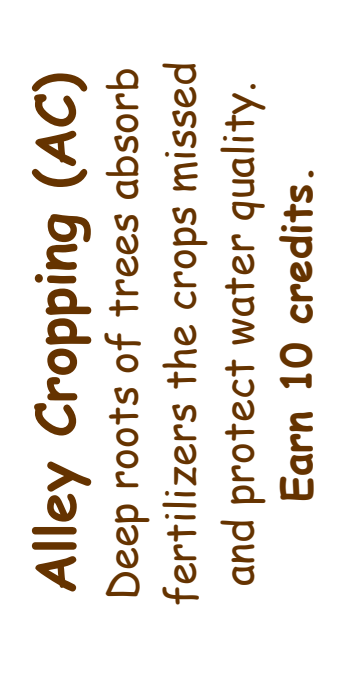 & 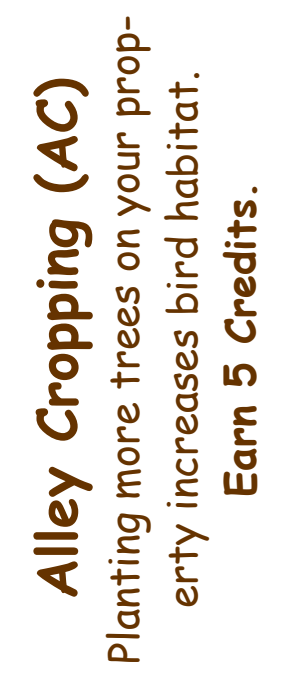 \\
\hline 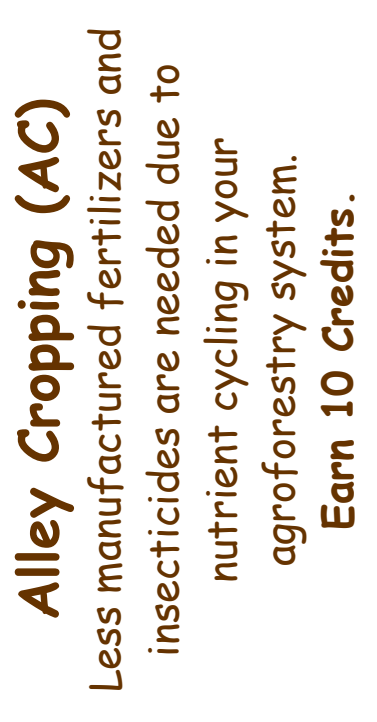 & 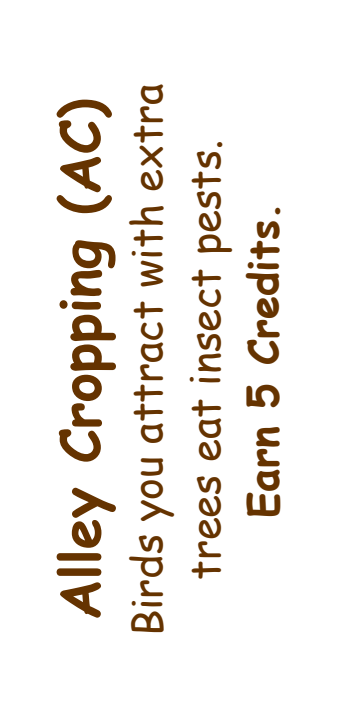 & 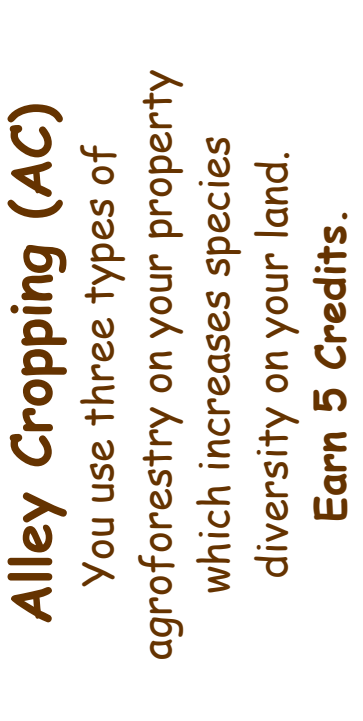 & 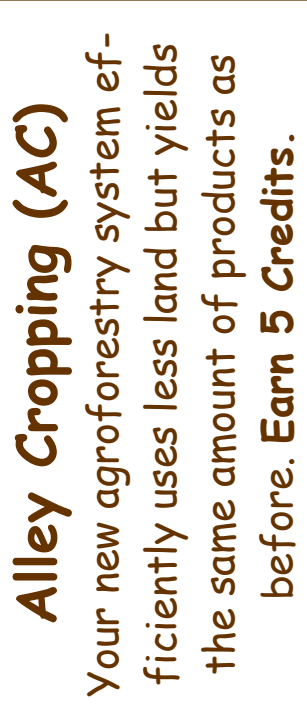 \\
\hline 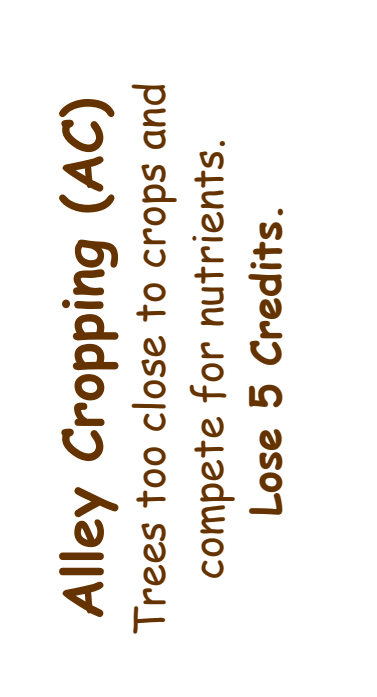 & 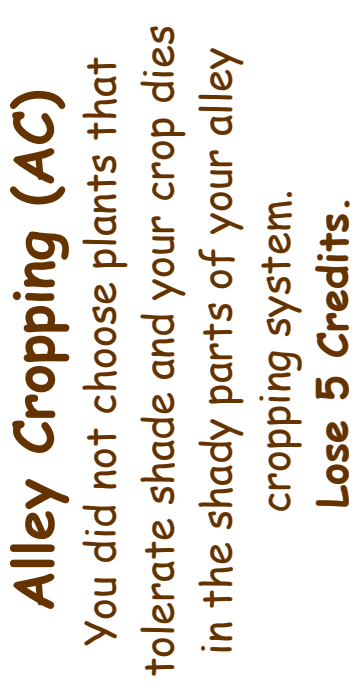 & 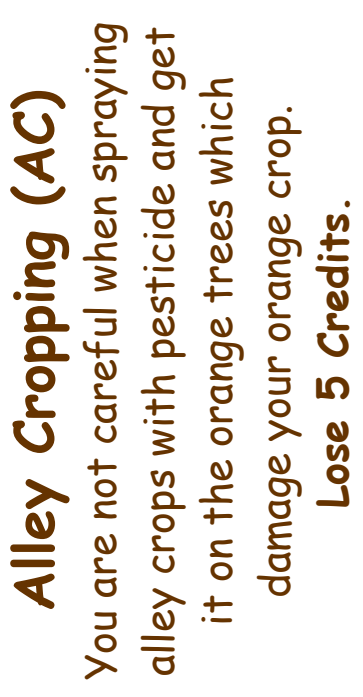 & 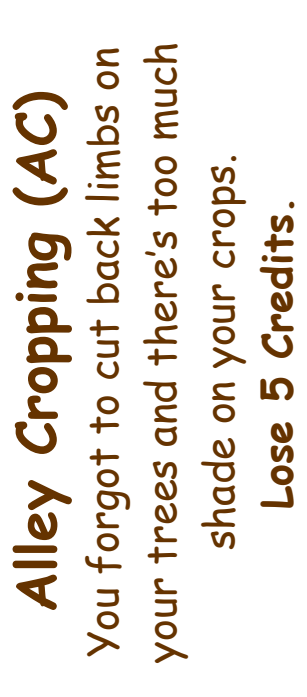 \\
\hline
\end{tabular}




\section{Silvopasture Cards - Green}

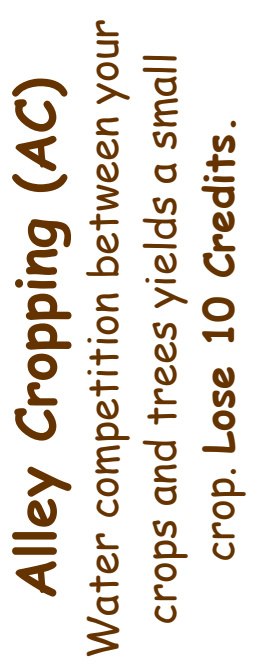

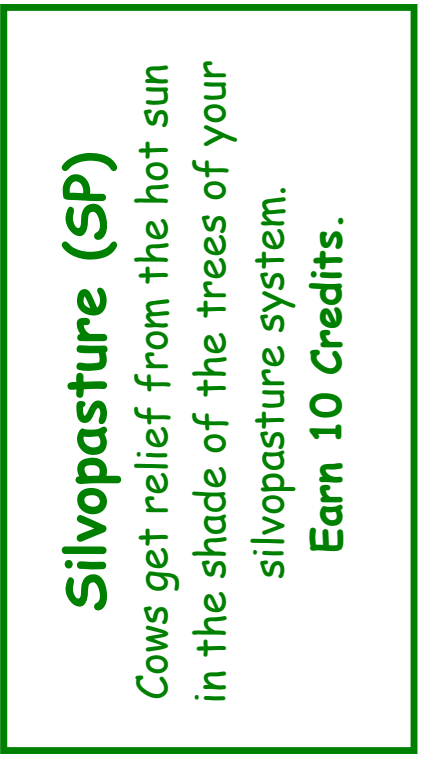
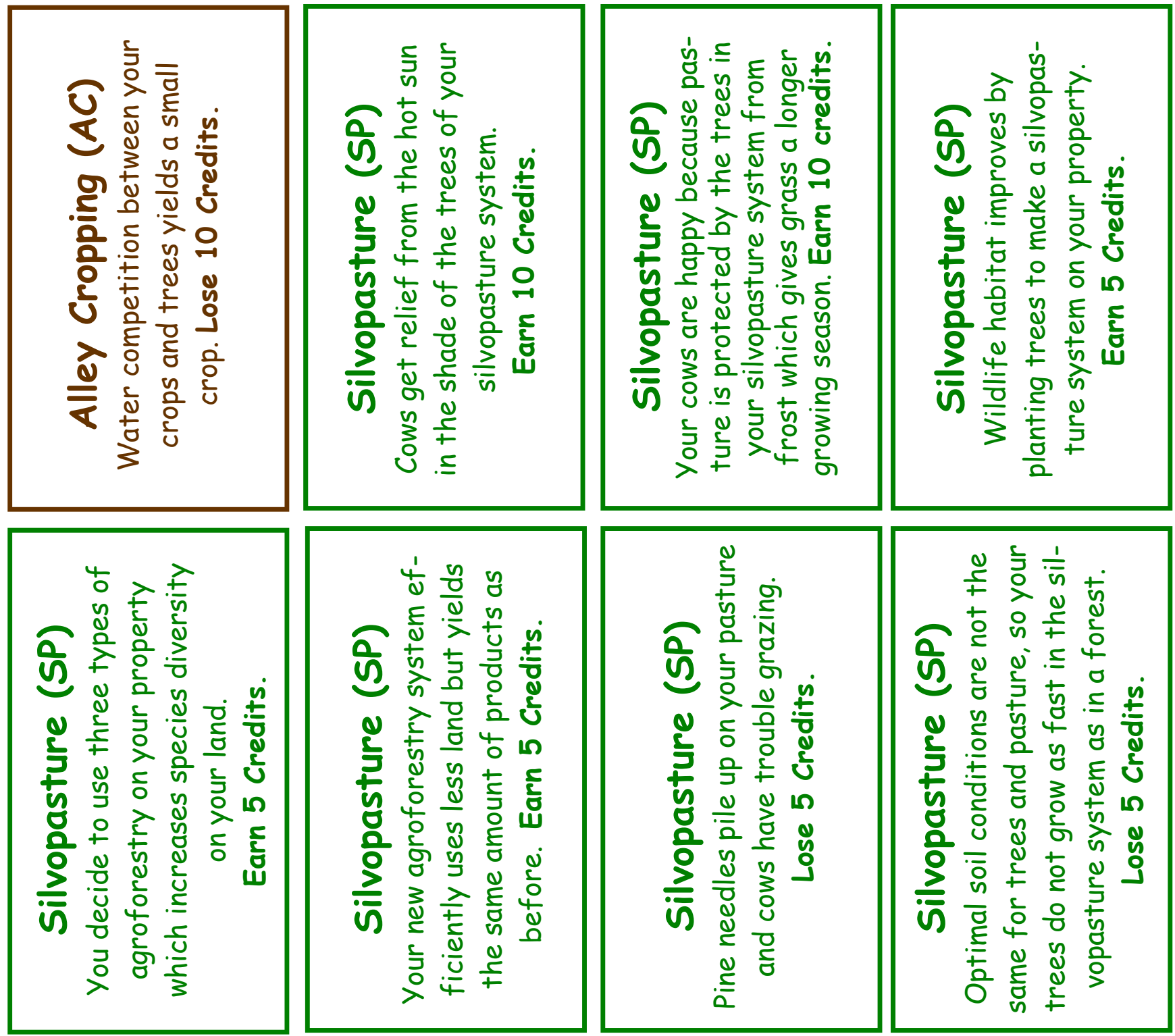

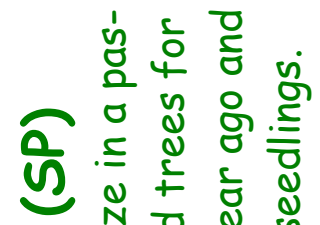

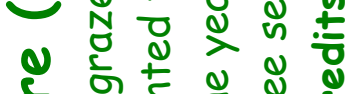

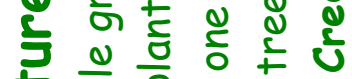

$$
\begin{aligned}
& \text { ध } \\
& \text { ด ริ } \\
& \text { ज } \frac{1}{2} \frac{0}{3} \frac{1}{5} \\
& \text { 워용 } \\
& \text { 긋 } \frac{1}{2} \frac{8}{\sqrt{n}}
\end{aligned}
$$


Forest Farming Cards - Blue

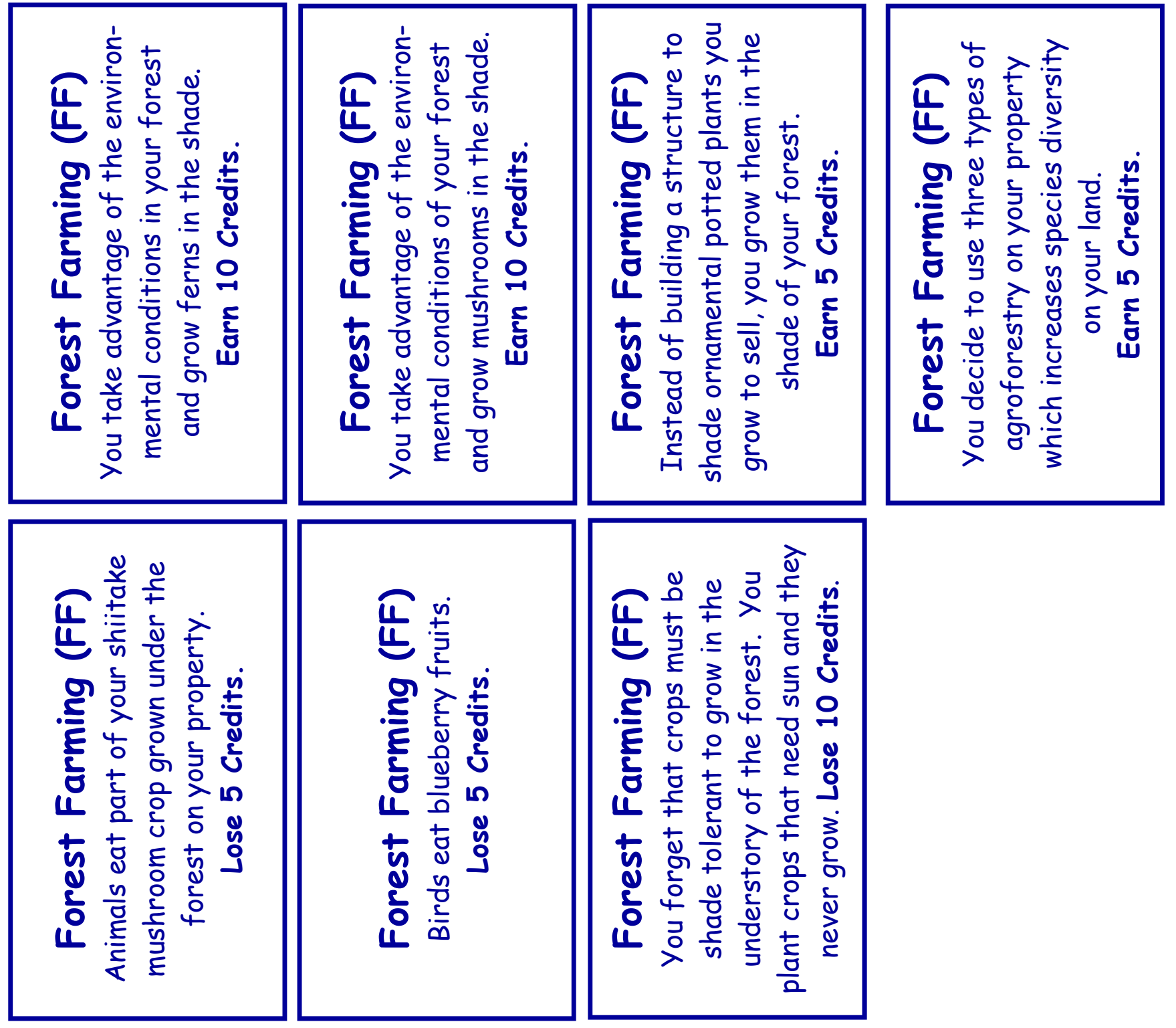

Riparian Forest Buster Cards - Red

\begin{tabular}{|c|c|c|c|}
\hline 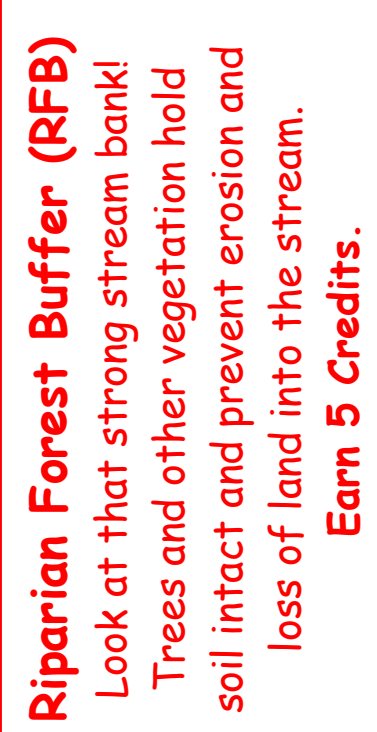 & 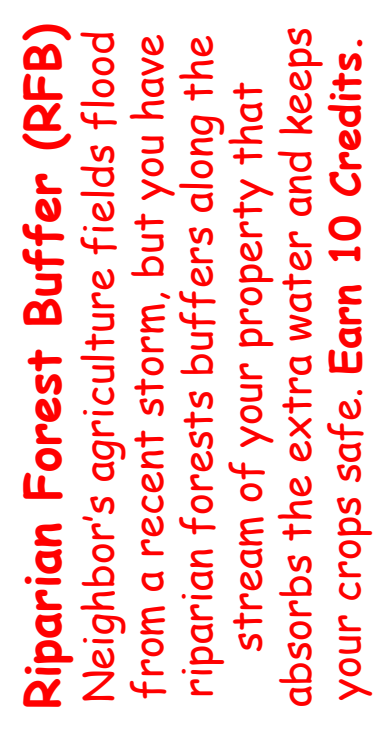 & 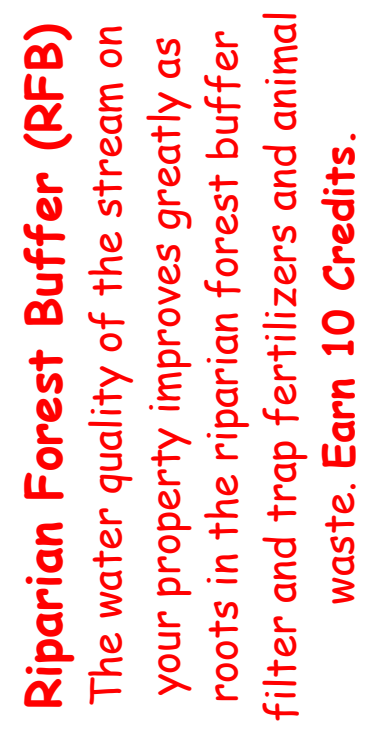 & 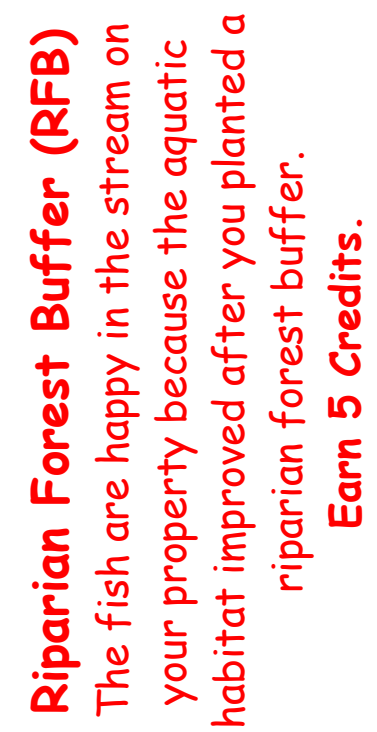 \\
\hline
\end{tabular}


Windbreak Cards - Purple

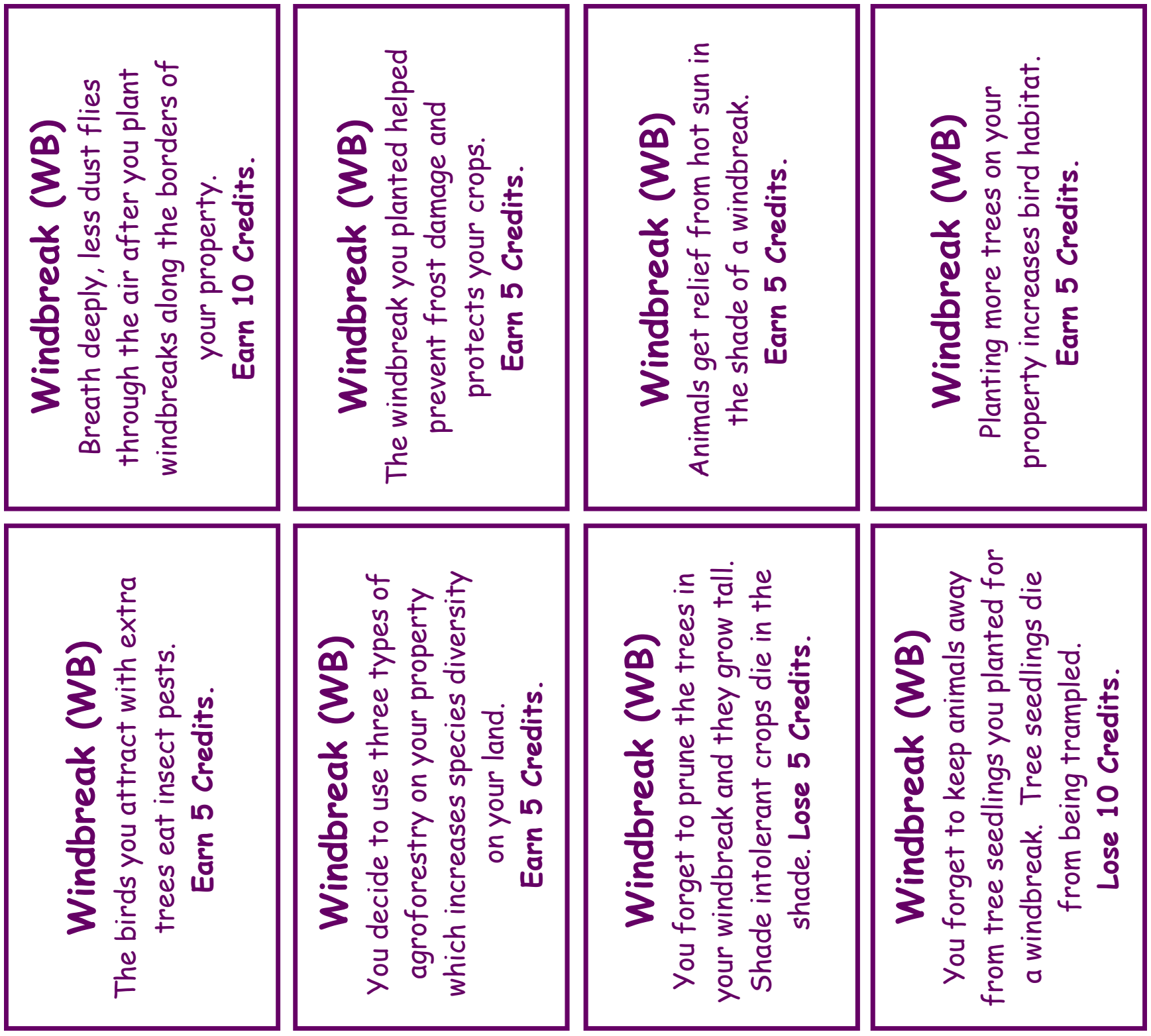

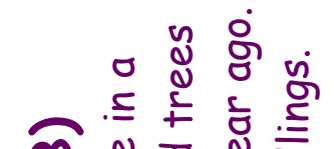

$$
\begin{aligned}
& \infty \text { N }
\end{aligned}
$$

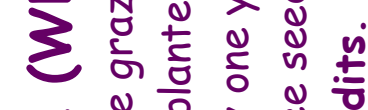

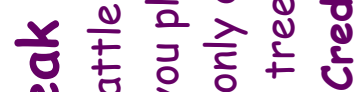

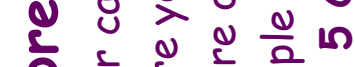

$$
\begin{aligned}
& \text { 을 }
\end{aligned}
$$

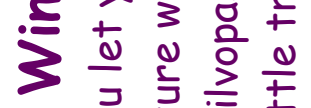

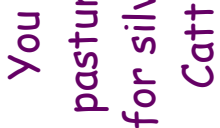




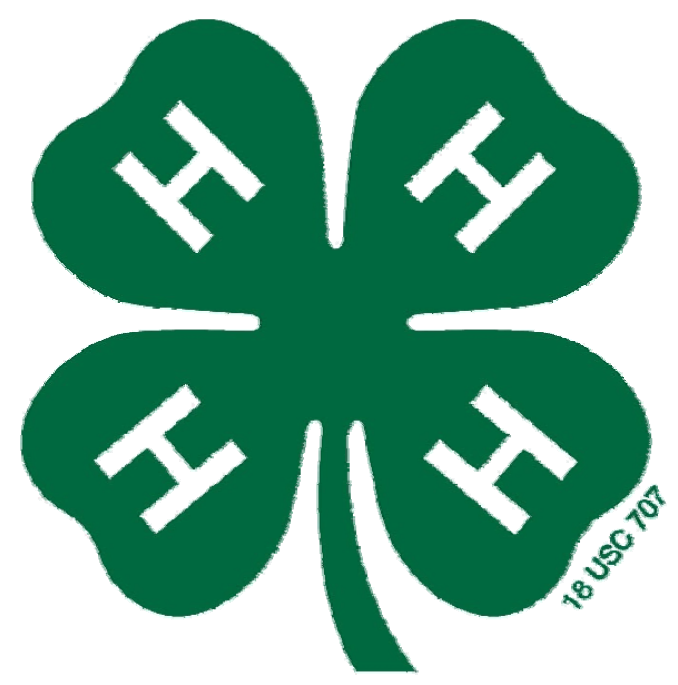

This publication was created by Julie Clingerman, Graduate Assistant, Alan Long, Associate Professor, School of Forest Resources and Conservation, Joy Jordan, Associate Professor/Curriculum Specialist, Department of Family, Youth \& Community Sciences, University of Florida, June 2005. Graphic Design by Laura Lok, Department of Family, Youth \& Community Sciences, University of Florida.

Special thanks to these reviewers Sharon Gamble, Extension Livestock Agent, Volusia County - Central; Lori Wiggins, Extension 4-H Agent Taylor County - Northwest; Jerry Culen, Associate Professor Environmental Education, Department of Family Youth and Community Sciences, University of Florida

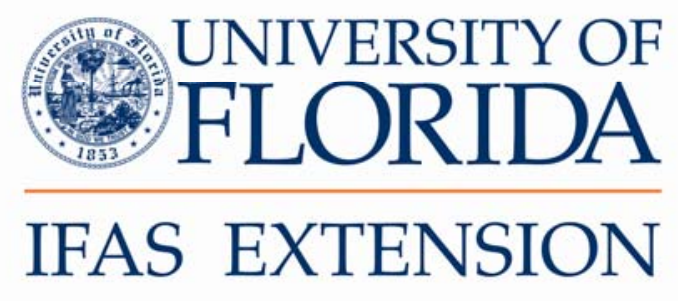

COOPERATIVE EXTENSION SERVICE, UNIVERSITY OF FLORIDA, INSTITUTE OF FOOD AND AGRICULTURAL SCIENCES, Larry R. Arrington, Director, in cooperation with the United States Department of Agriculture, publishes this information to further the purpose of the May 8 and June 30, 1914 Acts of Congress; and is authorized to provide research, educational information and other services only to individuals and institutions that function with non-discrimination with respect to race, creed, color, religion, age, disability, sex, sexual orientation, marital status, national origin, political opinions or affiliations. The information in this publication is available in alternate formats. Single copies of extension publications (excluding 4-H and youth publications) are available free to Florida residents from county extension offices. Information on copies for out-of-state purchase is available from IFAS-Extension Bookstore, University of Florida, PO Box 110011, Gainesville, FL 32611-0011. Information about alternate formats is available from IFAS Communication Services, University of Florida, PO Box 110810, Gainesville, FL 32611-0810. This information was published June 2005 as 4-H FOL 24, Florida Cooperative Extension Service. Reviewed June 2005. 